\title{
Performance management practices in humanitarian organisations
}

Hella Abidi

Sander de Leeuw

Department of Supply Chain Analytics, Vrije Universiteit Amsterdam, Amsterdam, The Netherlands and

Nottingham Business School, Nottingham Trent University, Nottingham, UK, and

Wout Dullaert

Department of Supply Chain Analytics, Vrije Universiteit Amsterdam, Amsterdam, The Netherlands

\begin{abstract}
Purpose - We examine how design and implementation practices for supply chain performance management that have proven successful in commercial organisations apply to humanitarian organisations (HOs) to guide the process of designing and implementing performance management in humanitarian organisations.

Design/methodology/approach - We identify from the literature ten successful practices regarding the design and implementation of supply chain performance management in commercial businesses. We apply these, using action research over a four-year period, at Médecins sans Frontières (MSF) Belgium and draw conclusions from this.

Findings - We find that tools and techniques, such as workshops and technical sheets, are essential in designing and implementing supply chain performance measurement projects at HOs. Furthermore, making a link to an IT project is crucial when implementing performance measurement systems at HOs. Overall, our case study shows that performance management practices used in business can be applied and are relevant for humanitarian supply chains.

Originality/value - Previous research has argued that there are few empirical studies in the domain of performance management at humanitarian organisations. To the best of our knowledge, this paper is the first to provide a longitudinal understanding of the design and implementation of supply chain performance measurement at HOs.
\end{abstract}

Keywords Empirical study, Performance measurement and management, Humanitarian supply chain, Performance management practices, Action research

Paper type Research paper

\section{Introduction}

To date, supply chain performance measurement at Humanitarian Organisations (HOs) has not been as systematically designed and implemented as in commercial companies or the military (Abidi et al., 2014; Vega, 2018). Once HOs did begin to address performance measurement and management, several key issues emerged (e.g. Beamon and Balcik, 2008). One such issue was how, in response to donor requests, to design and implement a supply chain performance measurement system that goes beyond financial indicators. The design and implementation of a supply chain performance measurement system is a particularly

(C) Hella Abidi, Sander de Leeuw and Wout Dullaert. Published by Emerald Publishing Limited. This article is published under the Creative Commons Attribution (CC BY 4.0) licence. Anyone may reproduce, distribute, translate and create derivative works of this article (for both commercial \& noncommercial purposes), subject to full attribution to the original publication and authors. The full terms of this licence may be seen at http://creativecommons.org/licences/by/4.0/legalcode.

Received 20 May 2019 Revised 30 September 2019 20 January 2020

Accepted 24 January 2020 
JHLSCM

10,2

complicated task at HOs due to the intangibility of the services offered, the immeasurability of their projects, unknown outcomes and the variety in the interests and standards of stakeholders (Beamon and Balcik, 2008). In addition, HOs need to have a process in place that ensures that, as circumstances change, performance management can evolve further (Abidi et al., 2014; Anjomshoae et al., 2019). Design and implementation is furthermore complicated by the lack of employee training, weak management commitment and unsupportive organisational culture, which limit supply chain performance measurement and management at HOs (Tatham and Hughes, 2011).

When it comes to performance measurement and management, the humanitarian sector stands in stark contrast with the business sector, where supply chain performance measurement and management have been commonplace for some considerable time and there is abundant literature on performance measurement design models and their implementation (e.g. Gutierrez et al., 2015). As such, performance measurement and management is seen as a fairly well researched topic in the business domain (Melnyk, 2014). A similar depth of research is lacking in the humanitarian supply chain literature (Abidi et al., 2014; Abidi and Scholten, 2015; Anjomshoae et al., 2017). In response, the objective of this research is to determine whether and how supply chain performance management practices used in business are applicable to HOs to guide the process of designing and implementing performance management in HOs. In addition, this research presents a process for managing the design and the implementation of performance management in HOs.

Our study focusses on two critical phases of performance measurement: its design and its implementation (e.g. De Leeuw and Van den Berg, 2011). The study was conducted over a four-year period at Médecins Sans Frontières (MSF) Belgium with the aim of designing and implementing a performance measurement system for their supply chain. MSF's supply chain strategy is to be flexible and to adapt effectively and rapidly to beneficiary (patient) demands. The emergency relief programmes that MSF are active in focus on response operations in the immediate aftermath of a disaster and are therefore typically characterized by a considerable uncertainty in needs (Saputra et al., 2015). To deal with these circumstances, the key supply chain objectives of MSF Belgium are flexibility and service, while maintaining focus on cost reduction and quality. Already in 2014, before the start of our study, MSF Belgium had restructured its supply chain and had created a new department responsible for the so-called End-to-End supply chain for all countries. The End-to-End supply chain encompasses all activities of a project starting from the assessment of relief needs to procurement from international and national suppliers, warehousing and distribution up to providing services to beneficiaries. Moreover, this new department responsible for the End-to-End supply chain was responsible for managing the associated human resources, material and financial demands and for information flows.

In this study at MSF Belgium, we focused on two main phases of performance measurement, design and implementation. The design phase consisted of an assessment of performance measurement methods and indicators already in use, the identification of supply chain objectives and the design of end-to-end key performance indicators. The implementation phase then involved collecting, analysing and disseminating the performance indicator data. We used action research to evaluate the applicability of ten supply chain performance management practices identified in the business literature for the design and implementation of HO performance measurement. We derived these practices from research presented by De Leeuw and Van den Berg (2011). We used various sources to support our findings and to evaluate the applicability of the performance management practices. These included monthly reports, internal documents, observations, discussions, interviews, workshops and meetings at MSF Belgium plus a visit to and interviews at three relief projects in Zimbabwe. Finally, in order to examine whether the 
performance management practices had been applied as intended, we validated their applicability during interviews.

We aimed to make theoretical and practical contributions. Firstly, we wanted to contribute to a deeper understanding of the design and implementation of supply chain performance measurement at HOs. Secondly, we sought to show how performance management practices used in business might be used by HOs to design and implement humanitarian supply chain performance measurement systems.

The remainder of the paper is structured as follows. The next section presents the theoretical background and a description of key performance management practices. Section 3 describes the research design and Section 4 details its application to the design and implementation phases of performance measurement. Section 5 provides the analysis of these performance management practices in the design and implementation of supply chain performance measurement at MSF Belgium. Section 6 provides a discussion of the results followed by the conclusions, limitations and future research directions.

\section{Theoretical background}

\subsection{Humanitarian vs business supply chains}

An area where performance management has witnessed considerable growth in attention is humanitarian supply chain management (Ahmed et al., 2019). This type of supply chain management deals with the coordination and integration of external stakeholders in a relief chain to rapidly provide humanitarian assistance to areas affected by large-scale emergencies (Cozzolino, 2012). As indicated earlier, this is a topic that has witnessed considerable achievements in the business sector. The humanitarian sector differs from the business sector in several important aspects. In order to summarise these, we build upon an existing framework, comprising nine features, developed by Beamon (2004).

The first feature of this framework focuses on the demand pattern. In business supply chains, the demand patterns for goods are typically fairly stable and predictable as the demand comes from fixed warehouses in relatively regular sets of quantities (Balcik and Beamon, 2008). Demand patterns in humanitarian supply chains are typically unpredictable in terms of timing, location, type and size because the demand often depends on the type and the impact of the disaster that has occurred, and the economic conditions of the country affected, all of which has to be first assessed (Beamon and Kotleba, 2006; Pateman et al., 2013). The second feature is related to lead time. Lead time in business supply chains is defined as the time between a customer placing an order and the delivery of the shipment to the customer. This lead time is typically based on an agreement determined by suppliers, manufacturers and retailers (Beamon and Balcik, 2008). In humanitarian supply chains, when confronted with an unanticipated quick-onset emergency, there is usually little or no time between a demand occurring (disaster striking) and the need for supplies (Beamon and Balcik, 2008, p. 11). The third feature relates to the distribution network configuration. In business supply chains, it is common practice to determine and select the required number and the most efficient locations of central and decentralised distribution centres in terms of achieving a given service level (Balcik et al., 2010; Schön et al., 2018). For humanitarian supply chains, it is challenging to determine and select the required number and the most efficient central and decentralised distribution centres in terms of responding to the needed demand due to the variety in magnitudes, locations and types of disasters (Gatignon et al., 2010). The fourth feature relates to inventory control. In business supply chains, the inventory is monitored and controlled based on the agreed lead time with customers and the required customer service level (Bottani et al., 2017). Humanitarian supply chains are more project-oriented and short-lived (Cozzolino, 2012), and therefore controlling and monitoring inventory is more challenging due to large variations in lead times, demands and locations (the affected area) (Balcik et al., 2016). The fifth feature relates to information flows and associated systems. Accurate information flows and
Performance management practices 
JHLSCM 10,2 associated systems are crucial in humanitarian supply chains because they impact response efficiency (Pettit and Beresford, 2009). In business supply chains, the information flow is often supported by advanced technology (Pettit and Beresford, 2009), whereas, in humanitarian supply chains, the information flow is often inaccurate or non-existent due to the infrastructure being destroyed in the disaster (Kovacz and Spens, 2011). The sixth feature relates to the strategic goals of the supply chain. Typically, business supply chains aim to produce high-quality goods at low cost to increase customer satisfaction, to maximise profits and to promote sustainability (Bals and Tate, 2018). In humanitarian supply chains, the HOs aim to minimise human suffering and target the distribution of critical and elementary relief items to beneficiaries in a way that achieves the greatest social good (Oloruntoba and Gray, 2009; Holguín-Veras et al., 2013; Baharmand et al., 2017). Next, feature seven relates to performance management, which is a common practice in business supply chains (Bititci et al., 2000) but lagging behind in humanitarian supply chains (Beamon and Balcik, 2008; Abidi et al., 2014). Performance management in humanitarian supply chains is particularly difficult due to the intangibility of services, immeasurability of the mission, unknown outcomes and the variety, different interests and standards of stakeholders (Beamon and Balcik, 2008). In terms of supply chain type (feature 8), humanitarian and business supply chains can both be characterized as dynamic and agile supply chains (Oloruntoba and Gray, 2006). Both supply chains operate in a constantly changing world with unpredictable demands and require transparency that enables timely and accurate information exchange (Scholten et al., 2009). Finally, humanitarian and business supply chains share a common view regarding the definition of supply chain management (feature 9). Both define supply chain management as the planning and coordination of all activities involved in sourcing and procurement, conversion, and all logistics management activities. It also includes cooperation and collaboration with channel partners, possibly including suppliers, intermediaries, LSPs (Logistics Service Providers) and customers (beneficiaries) (Beamon and Balcik, 2008; Richey et al., 2009).

\subsection{Performance management practices}

It has long been recognised that performance measurement and management is crucial for the effective and efficient management of logistics networks (Melnyk et al., 2014). Performance measurement and management contributes to the continuous improvement of performance (Neely et al., 1997), to the deployment of strategy (Kaplan and Norton, 2001), to organisational learning (Kueng et al., 2001), to managerial development (Garengo et al., 2005) and to aligning operations with strategic objectives (Taticchi et al., 2010). Performance measurement and management in humanitarian supply chains is still in its early stages compared to that in business supply chains.

Measuring and managing performance in a humanitarian supply chain is a concern and a challenge for academics and for practitioners (Abidi et al., 2014; Haavisto and Goentzel, 2015). Managing humanitarian supply chain performance is considered too difficult and too expensive to establish direct linkages between an organisation's annual efforts and the impact of those efforts on the organisation's mission (Anjomshoae et al., 2017).

A plethora of performance measurement and management frameworks have been developed for business supply chains (Atkinson, 2012) including the Balance Scorecard (Kaplan and Norton, 2001) and the SCOR model (Supply Chain Council, 2007). Such frameworks are undoubtedly valuable, but their adoption is often constrained by the fact that they offer little guidance on how to select appropriate organisation-specific indicators and how to practically implement the designed indicators within organisations (De Waal and Kourtit, 2013). Attempts have been made, for example by Gunasekaran et al. (2017) who focussed on assembling key metrics using literature and results of an empirical study of selected British companies and by Lai et al. (2002) and Huang et al. (2005) who present performance indicators that are based on reliability, responsiveness, costs and assets. Similarly, the work of Beamon offers three different 
indicator categories based on resources, output and flexibility (Beamon, 1999). In order to define practices that focus on designing performance measurement indicators and on implementing performance management, we conducted a literature review using an existing framework of performance management practices identified by De Leeuw and Van den Berg (2011).

2.2.1 Designing performance measurement systems. The initial design phase focuses on identifying an organisation's objectives and success factors in order to develop relevant performance indicators (Bourne et al., 2000). In the business sector, it is common to design and develop indicators using a standard performance measurement framework rather than a custom-made model (Najmi et al., 2012) (ID1 in Table I). The most commonly used performance measurement frameworks in supply chain management practice are the Balance Scorecard (BSC) (Kaplan and Norton, 2001) and the SCOR model (Supply Chain Council, 2007). Decision-makers use the BSC to evaluate business activities from financial, customer, learning and growth, and internal processes perspectives (Kaplan and Norton, 2001). The SCOR model distinguishes five supply chain processes and proposes associated performance indicators on four levels (Supply Chain Council, 2007). Both performance measurement frameworks are relevant to supply chain management as they help to derive indicators that link the environment and the strategy of an organisation. Linking environment and strategy is considered essential for delivering appropriate and costeffective supply chain performance (Melnyk et al., 2014). Operational performance indicators should be derived from strategic and tactical organisational objectives (Melnyk et al., 2014) (ID2 in Table I). Performance indicators should assess performance by measuring both quantitative and qualitative objective criteria (Gutierrez et al., 2015). Objective criteria need to be applied to identify standards and targets: either customer requirements, benchmarks or market standards, or time studies or historical data rather than estimates by management or operators (Taticchi et al., 2010) (ID3 in Table I).

Performance measurement can have a valuable role in creating a dialogue between the top management of an organisation and its divisions or subsidiaries and in avoiding any misinterpretation of the performance of divisions or subsidiaries (Gutierrez et al., 2015). As such, operational performance indicators should be defined jointly with all the departments involved, rather than by each department separately (Micheli et al., 2011) (ID4 in Table I) to achieve effective performance management (Tung et al., 2011). It has long been recognised that performance measurement and management are critical for the effective and efficient management of any business (Melnyk et al., 2014). However, flexibility should also be considered in determining metrics to ensure an ability to quickly react to changes (Ferreira and Otley, 2009) (ID5 in Table I). Table I summarises the best practices discussed above which have been supported by the empirical work of De Leeuw and Van den Berg (2011).

\begin{tabular}{|c|c|c|c|}
\hline & Practices & Sources & \\
\hline ID1 & $\begin{array}{l}\text { Define performance indicators according to a standard model, e.g. BSC or SCOR, } \\
\text { or a corporate standard model rather than a custom-made model }\end{array}$ & Najmi et al. (2012) & \\
\hline ID2 & $\begin{array}{l}\text { Derive operational performance indicators from the company's strategic and } \\
\text { tactical objectives }\end{array}$ & Melnyk et al. (2014) & \\
\hline ID3 & $\begin{array}{l}\text { Use objective criteria for defining standards and targets, either external } \\
\text { (customer requirements, benchmarks or market standards) or internal (time } \\
\text { studies or historical data), rather than estimates by management or operators }\end{array}$ & Tatticci et al. (2010) & Table I. \\
\hline ID4 & $\begin{array}{l}\text { Define operational performance indicators jointly with all the departments } \\
\text { involved, rather than by each department separately }\end{array}$ & Micheli et al. (2011) & $\begin{array}{r}\text { Best practices in } \\
\text { designing operational } \\
\text { performance }\end{array}$ \\
\hline ID5 & $\begin{array}{l}\text { Cover three aspects - efficiency, effectiveness and flexibility - in the } \\
\text { performance indicators }\end{array}$ & $\begin{array}{l}\text { Ferreira and Otley } \\
(2009)\end{array}$ & $\begin{array}{r}\text { measurement } \\
\text { indicators }\end{array}$ \\
\hline
\end{tabular}

Performance management practices

129 
JHLSCM

10,2

130

2.2.3 Implementing performance measurement. The subsequent implementation phase puts the performance measurement system and procedures into place (Bourne et al., 2000). Initiating and sustaining a performance measurement initiative is crucial for improving business performance (Nudurupati et al., 2011) (ID6 in Table II). Implementing performance measurement is primarily a mechanistic exercise (Bourne et al., 2000) and should be managed by team leaders and/or operators who are part of the implementation team (ID7 in Table II). The team leaders and/or operators should possess good business management skills and demonstrate a committed spirit (Franco-Santos et al., 2007).

Performance measurement implementation should be treated as part of an organisationwide project (Ukko et al., 2007) because this will enhance implementation success (Nudurupati et al., 2011) (ID8 in Table II). In order to fully understand the design and implementation of performance measurement, and to ensure the success of its implementation, the involvement of an external expert in performance management projects is recommended (Marchand and Raymond, 2008) (ID9 in Table II). Moreover, the successful implementation of performance measurement systems relies on top management commitment (Cavalluzzo and Ittner, 2004). Top management should ensure that people apply performance measurement systems at all levels of their decision-making (Kennerley and Neely, 2002) since these systems not only deliver performance improvements but also become a vehicle for cultural change, which helps to liberate the power of the organisation (Meekings, 1995). During implementation, explicit attention should be given to cultural change and/or to operator training in the new way of working (Franco-Santos et al., 2012) (ID10 in Table II). Here, training by officials and managers can reduce the resistance to using performance measurement systems (Battista and Verhun, 2000) and enhance skills and knowledge on analysing the results obtained from a performance measurement system and then making improvements (National Performance Management Advisory Commission, 2010). Table II lists the best practices discussed above which were again supported in the empirical work of De Leeuw and Van den Berg (2011).

\section{Research approach and execution \\ 3.1 Research approach}

The design and implementation of performance measurement systems in an organisation involves a change process that usually takes considerable time to develop (e.g. De Waal and Counet, 2009). For empirical and longitudinal research into this type of change, methods such as interviews, participant observations and action research are often recommended (e.g. Gutierrez et al., 2015). Compared to the interviews or observations used in a traditional case study, action research requires participative action and critical reflection and yields a deeper understanding of, in this case, performance measurement (Gutierrez et al., 2015). Action research can be

Table II.

Best practices in implementing operational performance measurement indicators

\begin{tabular}{lll}
\hline & Practices & Sources \\
\hline ID6 & $\begin{array}{l}\text { Initiate a performance management initiative to improve business } \\
\text { performance, i.e. cutting costs or improving customer service, rather than }\end{array}$ & Nudurupati et al. (2011) \\
non-business reasons such as complying with legislation or assessing/ & \\
rewarding operators & & \\
ID7 & $\begin{array}{l}\text { Pay explicit attention to cultural change and/or operator training in the } \\
\text { new way of working during implementation }\end{array}$ & $\begin{array}{l}\text { Franco-Santos et al. } \\
(2007)\end{array}$ \\
ID8 & Make team leaders and/or operators part of the implementation team & Ukko et al. (2007) \\
ID9 & $\begin{array}{l}\text { Involve an external expert in performance measurement or in } \\
\text { organisational change in the implementation }\end{array}$ & $\begin{array}{l}\text { Marchand and } \\
\text { Raymond (2008) }\end{array}$ \\
ID10 & Implement performance indicators as part of a company-wide project & $\begin{array}{l}\text { Franco-Santos et al. } \\
\text { (2012) }\end{array}$ \\
& &
\end{tabular}


characterised as a specific form of case study with the dual objectives of contributing to the practical concerns of an organisation while simultaneously accommodating the goals of science (Eltantawy et al., 2015). Action research is appropriate when seeking to take actions to solve problems and to develop knowledge and theory about that action (e.g. Coughlan and Coghlan, 2002). Action research takes place simultaneously with the action and is a sequence of activities that can be used to solve problems at an organisation (Coughlan and Coghlan, 2002). Moreover, action research is based 'on a collaborative problem-solving relationship between the researcher and practitioners, which aims at both solving a problem and generating new knowledge' (Coghlan and Brannick, 2010, p. 35).

Action research was adopted for our study because knowledge on performance measurement design and implementation needed to be built in close collaboration between researchers and practitioners (Bourne $e$ t al., 2005). This study was conducted over a period of four years at Médecins Sans Frontières (MSF) Belgium. The MSF organisation in Belgium asked the authors to design and implement a performance measurement system and to participate in the performance management project because of the complexity of developing performance measurement at HOs. The action research method is essentially longitudinal and empirical. Action research consists of problem identification, a solution formulation phase and a solution implementation phase. Working through such phases is one aspect of the 'rigour' in action research (Johnson et al., 2014). The performance management design and the implementation phases are each composed of five stages during the action research study: diagnosing, action planning, action taking, evaluating and specifying learning (Fagundes et al., 2017). The main action research phases in our study were as follows: (1) researchers involved in designing and in implementing performance measurement, and in understanding the processes of change and improvements in the processes; (2) tracking changes in performance measurement development in a real setting (participatory approach-Coughlan and Coghlan, 2002); (3) determining objectives and designing performance indicators; and (4) implementing and testing the designed performance indicators and providing a reflection on the results.

In action research, access to data and information about the topic being studied is important (da Mota Pedrosa et al., 2012). As part of this, gaining trust is a key criteria in action research in order to obtain information from employees. Gaining this information is a significant advantage of the action research approach as academic researchers cannot gain direct access to this know-how through questionnaire surveys (Coghlan and Brannick, 2010; Gutierrez et al., 2015). In our performance management project at MSF, we had access to both data and staff. We established a performance management working group at MSF Belgium consisting of practitioners (six supply chain officers and one supply chain director) and academic staff (one senior researcher and a $\mathrm{PhD}$ candidate (the main researcher)) to implement the design and implementation of a performance measurement system. The practitioners' presence was crucial in obtaining support for the design and implementation of the measurement system in the organisation. This presence, as recommended by Gutierrez et al. (2015), ensured the involvement of key actors and the necessary resources. The academic staff provided the theoretical foundations to develop the conceptual procedural framework and could provide insights into the development, opportunities and challenges of performance measurement at an HO. The senior researcher acted as a facilitator in developing an agreement among the performance management working group members. The main researcher acted as a coordinator and process enabler to provide training sessions, to ensure the involvement and participation of all actors, to organise workshops, to achieve a consensual validation of the performance measurement development (e.g. Gutierrez et al., 2015) and to design and test the developed indicators using real project data.
Performance management practices 
JHLSCM

10,2

\subsection{Designing performance measurement}

The design phase started with a kick-off meeting with employees from different departments at the headquarters of MSF Belgium. This meeting was organised by the supply chain director and the main researcher. After the meeting, we first reviewed and assessed the performance indicators then used by MSF Belgium. The review and assessment of the existing performance measurement was based on internal documents, semi-structured interviews (Appendices 1 and 3) and monthly reports as recommended by Braz et al. (2011). We furthermore identified the key objectives linked to MSF Belgium's supply chain based on 14 semi-structured interviews (Appendices 1 and 3). These interviews were conducted with medical staff, finance officers and director, supply chain officers and director, back-office staff (warehouse management), technicians, logisticians and supply managers who were involved in various projects worldwide (Table III). The interview process used to assess performance measurement was based on questions developed by Neely et al. (1997) and Kennerley and Neely (2002). It consisted of five main parts: (1) the introduction of the interviewer and interviewee, the scope of the research project and assurances of confidentiality; (2) the role of the interviewee at MSF Belgium; (3) definition of a successful humanitarian supply chain and the supply chain at MSF Belgium, key objectives, key processes, the structure and strategy linked to the agile humanitarian supply chain of MSF Belgium, and the service level required by donors and beneficiaries; (4) bottlenecks and gaps in the supply chain as well as software used and data collection capabilities; and (5) specific questions on performance management (i.e. existing KPI frameworks, implementing performance management) (Appendices 1 and 3).

Following this, the main researcher made an inventory of existing performance indicators at MSF Belgium and mapped the extent to which these indicators covered all the supply chain processes at MSF Belgium. We then used the SCOR model and BSC to identify gaps in the supply chain processes that were not well covered by existing metrics. This also enabled us to ensure that the designed performance indicators would cover efficiency, effectiveness and flexibility (e.g. Lu et al., 2016).

Next, as recommended in Gutierrez et al. (2015), the availability of data was checked to identify whether all the performance indicators (existing plus newly suggested ones) could be measured. For some performance indicators, data sources were not readily accessible because

\begin{tabular}{lcc}
\hline Job position & $\begin{array}{c}\text { Experience in humanitarian aid } \\
\text { (years) }\end{array}$ & $\begin{array}{c}\text { Experience in supply chain management } \\
\text { (years) }\end{array}$ \\
\hline Back office & 9 & 11 \\
Medical Cell & 13 & 0 \\
Finance Director Supply & 0.5 & 0 \\
Unit & 25 & 0 \\
Chief Supply Chain & 23 & 20 \\
Middle Manager OPS & & \\
Logistics & 23 & 30 \\
Back office & 18 & 8 \\
Supply Chain Officer 1 & 8 & 11 \\
Supply Chain Officer 2 & 16 & 6.5 \\
MSF Supply Site Director & 16 & 0 \\
Middle-Manager Finance & 11 & 9 \\
Supply Chain Director & 11 & 11 \\
Supply Polyvalent & & 4 \\
Technician & 5.5 & 12 \\
Logistics Coordinator & 11 & \\
Project Supply Coordinator & &
\end{tabular}

Table III.

The employees interviewed 
some data were not entered into existing systems but rather held on paper or in spreadsheet documents. To avoid manual data collection and potentially conflicting data, an IT project was created in parallel by IT experts at MSF Belgium to enable data to be entered in an electronic format. These IT experts were also involved in the performance management project to provide opportunities and explain limitations regarding data entry in using the designed performance measurement indicators, a process in line with suggestions by Bourne et al. (2000).

Fourth, the performance indicators identified were ranked using scoring sheets by the members of the performance management working group during a workshop. The outcomes of this workshop were used as input for an Analytical Hierarchy Process (AHP) analysis. The AHP analysis was used to determine the most important performance indicators in evaluating supply chain performance at MSF Belgium (Appendix 4). This highlighted that the resulting indicators did not fully match the supply chain objectives of MSF Belgium. Therefore, in line with the suggestions of Braz et al. (2011), we used a technical sheet (Appendix 2) based on Neely et al. (1997) to evaluate the most important performance indicators and to ensure the appropriateness of the performance indicators for each supply chain process and for each organisational supply chain level.

Finally, the main researcher organised a follow-up workshop with the members of the performance management working group (supply chain officers, supply chain managing director, head of supply and supply chain director) to identify an appropriate measurement procedure, a step again suggested by Gutierrez et al. (2015). In this, we asked the members of the performance management working group the following questions (Appendix 6): (1) How can we operationalise these performance indicators? (2) Can we establish a target for each indicator? (3) What is an appropriate data gathering method? (4) Are the indicators effective? In practice, it took the working group $12 \mathrm{~h}$ to achieve consensus on the indicators and their measurement. The final version was presented to the advisory board by the supply director and supply chain director in order to gain approval for its implementation.

\subsection{Performance measurement implementation}

We structured the implementation phase in two main steps. The first step dealt with the organisational implementation of performance management at MSF Belgium. Weekly meetings were organised with the members of the performance management working group. We discussed the performance indicators, the data collection, we reviewed performance management procedures and we analysed the performance management culture at MSF Belgium.

The second step focused on actually measuring the supply chain performance of MSF projects using the key performance indicators determined in the design phase. Through this second step, involving an MSF supply seminar in Belgium, we aimed to obtain the commitment of managers in relief projects worldwide by showing them how to analyse the supply chain performance of projects (Appendices 5 and 6). We furthermore provided training sessions and seminars to the managers and operating groups. Additionally, we visited three relief projects in Zimbabwe. For each project we discussed the performance measurement implementation strategy (Appendix 6; some details are omitted for reasons of confidentiality). In Zimbabwe, we had daily meetings, organised by the supply manager and the main researcher, with MSF employees: the supply manager, warehouse manager, logistics officer, medical coordinator, pharmacists and the project heads of the relief projects. During each meeting, we analysed the performance of the selected projects and performance indicators were discussed, critically reviewed and adjusted.

Upon return to Europe, the main researcher set up further weekly meetings at MSF Belgium with the support of the supply chain director. The objective of these weekly meetings was to refine the key performance indicators and to establish a data collection system based
Performance management practices 
JHLSCM

10,2

on inputs obtained. The main researcher acted as a reviewer in these meetings. Furthermore, the main researcher provided an analysis of the supply chain performance of the three relief projects in Zimbabwe as examples for the advisory board of MSF Belgium. Finally, the supply director and the supply chain director at MSF Belgium presented this supply chain performance analysis to the top management at MSF Belgium (the advisory board). The related timeline including the major steps is presented in Figure 1

\section{4}

\section{Design and implementation of performance measurement at MSF}

This section presents and analyses the application of the ten selected performance management practices at MSF Belgium (see Table VI). These management practices, their operationalisation and tools are summarised in Table IV (design) and Table V (implementation).

\subsection{Performance measurement design}

4.1.1 Action research and analysis at MSF Belgium. To start the project, two members of the performance management working group organised a kick-off meeting. In line with practice ID4 (see Table IV - we use the same ID numbers as in the literature review in Section 2), the members of the performance management working group invited employees from a range of departments. During this kick-off meeting, we discovered that there had already been several initiatives by different departments to establish supply chain performance indicators.

During the kick-off meeting, all the existing indicators used at MSF Belgium were discussed. It became apparent that the indicators did not fully cover supply chain performance, were input-oriented (e.g. expiry date of products, incoming donation, transportation and warehouse costs, workload, fuel consumption, total stock value) rather than output-oriented (e.g. service level, delivery quality, customs clearance time, productivity of delivery vehicles) and did not allow performance to be compared across projects because virtually every project had its own indicators. Furthermore, we saw that the performance indicators used in these projects did not fully match MSF Belgium's supply chain objectives. We saw that different departments had different expectations with regard to supply chain objectives: (1) the financial department aimed at reducing supply chain costs and improving supply chain cost transparency and visibility; (2) the medical department sought a more rapid response to changes in demand by beneficiaries (patients) by increasing flexibility; and (3) the supply chain department targeted cost efficiencies and quality as well as service-level enhancement. This led, for example, to medical staff preferring to have an abundance of stock, whereas the stock manager from the supply chain department focused on limiting stocks to reduce warehouse costs and to avoid product expiry and damage. Participants at the kick-off meeting argued that this situation was due to unclear and only implicit communications about the supply chain's performance objectives and the agile supply chain strategy of MSF.

Next, we aimed to establish objective criteria for defining standards and targets (practice ID3). For this purpose, we carried out interviews with the supply chain's top management, supply chain officers, the financial director and officers from the relief projects and, further, evaluated internal documents with regards to the mission of the End-to-End supply chain. The outcomes of the interviews were documented in a mind-map that helped to identify the key objectives of the supply chain and how they related to the supply chain strategy of MSF. This mind-map was discussed in a meeting with the interviewees that was facilitated by the main researcher. Although some specific project and country differences arose during the meeting, there was general agreement about the core objectives reflected in the mind-map (included in Appendix 7). The team used two standard models (the SCOR model and the BSC) as well as an overview of existing indicators to develop a long list of 75 performance 
Performance

management

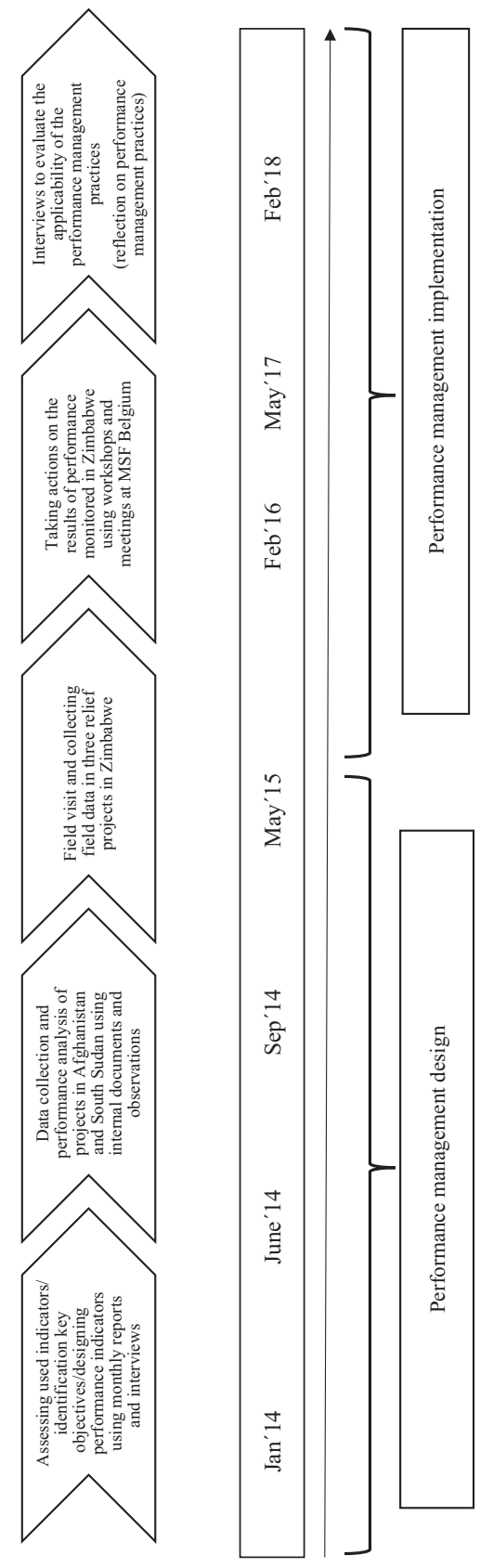

practices

135

Figure 1.

Timeline of performance management at MSF 


\section{JHLSCM 10,2}

\section{6}

Performance management practice Operationalisation and tools used

ID4 Jointly define operational performance indicators with all departments involved, rather than by each department separately

ID3 Use objective criteria, either external or internal, in defining standards and targets rather than estimates by management or operators

ID1 Define performance indicators according to a standard model, e.g. BSC, SCOR

ID2 Derive operational performance indicators from strategic and tactical company objectives

ID5 Cover all three aspects - efficiency, effectiveness and flexibility - in the performance indicators
Table IV.

Performance management practices in the design phase
Organisation of a kick-off meeting of the performance management group at the headquarters of MSF Belgium to clarify MSF Belgium's supply chain strategy (Appendices 1 and 3)

Identification of the key objectives linked to MSF Belgium's strategy and its supply chain strategy using interviews (Appendix 3) and a mind-map (Appendix 7)

Identification of whether, and if so to what extent, these performance indicators are also relevant when evaluating the supply chain performance at MSF Belgium and to reduce the number of performance indicators through on-site meetings with employees from different divisions (Appendix 3), application of the Analytical Hierarchy Process (Appendix 4) and a workshop

Ensuring the appropriateness of the performance indicators for each supply chain process and for each organisational supply chain level through a workshop and a technical sheet (Appendix 2) Agreement over the design of performance indicators that cover all three aspects (efficiency, effectiveness and flexibility), establishment of a measurement procedure and enhancement of the performance management culture within the operating group at MSF Belgium through a workshop and a technical sheet (Appendixes 2 and 6)

indicators (practice ID1). We then organised a meeting with the members of the performance management working group to develop, using a scoring sheet, a shortlist of indicators. This reduced the long list of 75 indicators to a more manageable 25 performance indicators. Using standard models, the BSC and SCOR, helped to ensure that output-oriented indicators (such as upside supply chain flexibility[1] or donation-to-delivery time) were also included along with indicators reflecting outcome, adaptability, accountability and impact (as also noted by Abidi and Scholten, 2015). The use of a standard model also helped ensure the indicators comply with MSF's agile supply chain strategy (practice ID2).

Following this, a four-hour workshop with members of the performance management working group was organised. In this meeting, the shortlist of 25 performance indicators was matched with the mind-map to check the extent to which key performance objectives were well covered. This workshop was aimed at sharing the views of the members of the performance management working group (consisting of both operational staff and management) and establishing a common understanding of the selected performance indicators. The advisory board wanted to have a maximum of five performance indicators at the strategic level (but did not place limitations on the number of indicators at the operational and tactical levels). For this purpose, an Analytical Hierarchy Process (AHP) model[2] was developed to identify the performance indicators that could best provide a picture of supply chain performance at strategic, tactical and operational levels[3]. AHP is a standard method used to evaluate trade-offs between alternatives. It is commonly used in supplier evaluation, and also in key performance indicator selection (Stricker et al., 2017), and can be used with relatively small numbers of respondents (cf. Abidi et al., 2019). The completed AHP was presented to the members of the performance management working group who were critical 


\begin{tabular}{|c|c|c|c|}
\hline & Performance management practice & Operationalisation and tools used & ertormans \\
\hline ID9 & $\begin{array}{l}\text { Involve an external expert, skilled in } \\
\text { performance measurement or organisational } \\
\text { change, in the implementation }\end{array}$ & $\begin{array}{l}\text { Academic staff with a background in consultancy } \\
\text { and practice were invited to carry out the design } \\
\text { and the implementation phases of performance } \\
\text { management at MSF Belgium }\end{array}$ & practices \\
\hline ID8 & $\begin{array}{l}\text { Make team leaders and/or operators part of the } \\
\text { implementation team }\end{array}$ & $\begin{array}{l}\text { Two team leaders were involved: one team leader } \\
\text { on the strategic level and the second on the tactical } \\
\text { and operational levels (Appendices } 2 \text { and 5) }\end{array}$ & $1:$ \\
\hline ID6 & $\begin{array}{l}\text { Introduce a performance management initiative } \\
\text { in order to improve business performance, i.e. } \\
\text { cutting costs or improving customer service, } \\
\text { rather than for non-business reasons such as } \\
\text { complying with legislation or assessing } \\
\text { operators }\end{array}$ & $\begin{array}{l}\text { A one-week supply seminar was held in Belgium to } \\
\text { discuss general supply chain improvements and } \\
\text { the performance management project. Supply } \\
\text { managers from } 29 \text { different projects in various } \\
\text { countries attended (Appendix 5) }\end{array}$ & \\
\hline ID10 & $\begin{array}{l}\text { Implement performance indicators as part of a } \\
\text { companywide project }\end{array}$ & $\begin{array}{l}\text { An implementation strategy was developed with } \\
\text { the performance management working group. } \\
\text { Further, the designed performance indicators were } \\
\text { demonstrated using data from } 12 \text { projects in } \\
\text { Afghanistan and South Sudan. Results were } \\
\text { presented during the one-week supply seminar }\end{array}$ & \\
\hline ID7 & $\begin{array}{l}\text { Give explicit attention to cultural change and/or } \\
\text { operator training }\end{array}$ & $\begin{array}{l}\text { A visit to three relief projects in Zimbabwe to } \\
\text { collect data and measure performance in these } \\
\text { projects (Appendix } 5 \text { and performance } \\
\text { measurement matrix - data not presented due to } \\
\text { confidentiality reasons) } \\
\text { A standard approach determined in conjunction } \\
\text { with the team leaders (data again confidential) }\end{array}$ & $\begin{array}{r}\text { Table V. } \\
\text { performance } \\
\text { management practices } \\
\text { implementation phase }\end{array}$ \\
\hline
\end{tabular}

of the outcome, in part because they believed completing the pairwise comparison survey would require too much effort. The results of the AHP analysis also failed to match the key supply chain objectives. For example, the performance indicator 'invoice accuracy' scored higher than 'percentage of shipments received with missing quantities or with damaged or incorrect goods' despite the latter being more beneficiary-focused and therefore more in line with MSF supply chain objectives. Deriving performance indicators from strategic, tactical and operational organisational objectives helped the participants understand that certain performance indicators were necessary, such as 'percentage of donation value unplanned' and 'percentage of orders created vs. orders responded to' (output-oriented indicator) alongside 'average number of order lines per day (incoming workload)' (input-oriented indicator).

During a further attempt to create a shortlist of appropriate performance indicators, the research team changed the approach and asked the members of the performance management working group to complete a performance indicator technical sheet (Appendix 2) based on Neely et al. (1997). Schreyer (2008) and Sousa et al. (2010) recommended using this technical sheet as its use ensures that measures are clearly defined and contribute directly to the associated continuous improvement programme. This technical sheet (Appendix 2) includes information on each performance indicator in terms of its purpose, format, target, responsibility, data source and frequency of reporting, and on the use of these performance indicators. In completing the technical sheet, we also asked the members of the performance management working group to match each performance indicator with an operational, tactical or strategic objective of the agile supply chain of MSF Belgium. While completing this sheet, participants noted that some of the performance indicators overlapped. They also realised that some performance indicators such as 'demand 


\section{JHLSCM 10,2}

Practice

Participation

Performance management practices in the design phase

Organisation of a kick-off meeting of the performance management group at the headquarters of MSF Belgium to clarify MSF Belgium's supply chain strategy (Appendices 1 and 3)

Identification of the key objectives linked to MSF Belgium's strategy and its supply chain strategy using interviews (Appendix 3) and a mind-map (Appendix 7)

Identification of whether, and if so to what extent, these performance indicators are also relevant when evaluating the supply chain performance at MSF Belgium and to reduce the number of performance indicators through on-site meetings with employees from different divisions (Appendix 3), application of the Analytical Hierarchy Process (Appendix 4) and a workshop

Ensuring the appropriateness of the performance indicators for each supply chain process and for each organisational supply chain level through a workshop and a technical sheet (Appendix 2)

Agreement over the design of performance indicators that cover all three aspects (efficiency, effectiveness and flexibility), establishment of a measurement procedure and enhancement of the performance management culture within the operating group at MSF Belgium through a workshop and a technical sheet (Appendices 2 and 6)

\section{Performance management practices implementation phase}

Academic staff with a background in consultancy and practice were invited to carry out the design and the implementation phases of performance management at MSF Belgium

Two team leaders were involved: one team leader on the strategic level and the second on the tactical and operational levels (Appendices 2 and 5)

A one-week supply seminar was held in Belgium to discuss general supply chain improvements and the performance management project. Supply managers from 29 different projects in various countries attended (Appendix 5)

An implementation strategy was developed with the performance management working group. Further, the designed performance indicators were demonstrated using data from 12 projects in Afghanistan and South Sudan. Results were presented during the one-week supply seminar

A visit to three relief projects in Zimbabwe to collect data and measure performance in these projects (Appendix 5 and performance measurement matrix - data not

Table VI. presented due to confidentiality reasons)

Participation during the project confidential)
A standard approach determined in conjunction with the team leaders (data again
(1) Academic staff

(2) Supply chain director

(1) Academic staff

(1) Academic staff

(2) Supply chain director

(3) Supply chain officers

(1) Academic Staff

(1) Academic staff

(2) Supply chain director

(3) Supply chain officers

(1) Supply chain director

(1) Academic staff

(2) Supply chain director

(1) Academic staff

(2) Supply chain director

(1) Academic staff

(1) Academic staff

forecast accuracy' provide more valuable insights than others such as 'demand accuracy'. In order to reach a consensus, we used the technical sheet and discussed each performance indicator during a workshop. Using the technical sheets, the 25 performance indicators were first sorted into operational, tactical and strategic indicators in a project meeting. The members of the performance management working group then reviewed the indicators by category and looked for overlap between the three categories. The strategic indicators were reduced to five, as requested by the advisory board, while ensuring a good balance between performance indicators (an approach suggested by Braz et al. (2011)). The focus on covering the key supply chain objectives in choosing indicators ensured coverage of efficiency, effectiveness and flexibility (ID5). During a workshop with the members of the performance management working group, we used the technical sheet to identify performance indicators that would cover the categories of efficiency (i.e. indicators focused on costs), effectiveness 
(focused on time) and flexibility (in resources). For this purpose, we used the technical sheet to detail the contents of each performance indicator. The efficiency category, for example, contained total delivery cost; the effectiveness category included on-time delivery and the flexibility category included stock level (to enable a rapid reaction when necessary).

These five steps (ID1 to ID5) are summarised in Table IV below. In the next section, based on interviews with the supply chain director, a project leader and the supply director of MSF Belgium, we reflect on the performance management design practices. We discuss the practices in the order of application in the project, which is not always the same as the order in the tables above.

4.1.2 Reflection on performance management design practices. The interviewees confirmed the usefulness of having a kick-off meeting in which all departments were involved (practice ID4). Here, the interviewees argued that applying practice ID4 had led employees to reflect on their own activities using inputs from different perspectives and to think about indicators that encompass the entire supply chain rather than a single node or link in that supply chain. In addition, it was noted that the meeting resulted in attendees promising to provide the data and information necessary for designing and testing performance indicators.

As a second step in the design phase, we used a mind-map to identify objectives and targets that are required for designing performance indicators (ID3). Practice ID3 was considered effective for designing performance measurements with the interviewees asserting that the objectives and targets should be the starting point for designing performance indicators when addressing a complex supply chain such as at MSF Belgium. According to the interviewees, this also contributes to gaining an understanding of the purpose and use of indicators within the performance management working group (i.e. as an indication of how far you are away from your objectives).

Third, we defined additional performance indicators based on a standard model (ID1). The interviewees appreciated practice ID1 because it enabled the performance management working group to combine indicators from standard models (slightly adjusted to accommodate the specifics of MSF) with existing indicators during the design phase. The interviewees argued that combining different indicators (from standard models and some in current use) is necessary because existing standard models are not directly applicable when evaluating humanitarian supply chains. Nevertheless, drawing ideas from standard models, such as SCOR and BSC, was useful. Using standard models was also a way to ensure that the focus when designing indicators went beyond existing operational indicators and included tactical and strategic indicators. Furthermore, the interviewees recommended using only the technical sheet when selecting performance indicators since the AHP model was considered as too time-consuming and overly complex. They indicated that they viewed the application of the technical sheet as a pragmatic tool to achieve a consensus on performance indicators. We designed, during a workshop with the performance management group, performance indicators based on the strategic and tactical supply chain objectives of MSF Belgium. The interviewees saw ID2 (derive operational performance indicators from the company's strategic and tactical objectives) as necessary because deriving indicators from the strategic (headquarter) and tactical (coordination) levels enabled links to be created between the strategic, tactical and operational levels. This linking of the three levels is crucial in identifying the impact of one level on the others. Practice ID2 also helped in clarifying crucial starting points, such as MSF's agile supply chain, to employees. This understanding contributes to data quality because people are then more willing to pay closer attention to correctly entering data in systems. The interviewees argued that, particularly in some African countries, MSF has more problems with data quality than, for example, in some Asian countries. They also indicated that the variety of IT systems used at MSF hinders achieving good data quality (which was one of the reasons for setting up the overall KPI project).
Performance management practices 
JHLSCM

10,2

140

To verify that the designed indicators covered all three aspects (efficiency, effectiveness and flexibility - ID5), we used the technical sheet during a workshop with the performance management group. The interviewees agreed that practice ID5 was useful because taking all three aspects into account was helpful in ensuring the correct indicator design decisions were taken. All the interviewees indicated that covering all three aspects is relevant to establishing MSF's current performance and in determining whether MSF is on the right track to achieve its supply chain strategy.

We also discussed the relative importance of the practices. Overall, the interviewees argued that ID3 was the most important because clarifying an HO's supply chain objectives is crucial if one is to design appropriate supply chain performance indicators. ID4 was evaluated as the second most useful, ID2 as the third, with ID1 and ID5 less important but still valuable.

\subsection{Implementation of the new performance measurement framework}

4.2.1 Action research and analysis at MSF Belgium. Not surprisingly, the implementation phase is critical in performance management (De Waal and Counet, 2009). As structured and standardised performance assessments of the supply chain were not yet common practice at MSF Belgium, the supply chain director decided to involve the authors of this study as an external expert team (ID9- using the same ID numbers as in the literature review in Section 2) with academic and consultancy experience not only for the design but also for the implementation of a performance measurement system at MSF Belgium. Many authors recommend involving an external expert to achieve a full understanding of performance management and to ensure the successful implementation of a performance measurement system (e.g. Marchand and Raymond, 2008). Not only the project team but also the advisory board at MSF considered external support in the implementation phase as important in guiding decision-making and preventing commonly made mistakes, and to provide extra capacity and knowledge on the topic of performance measurement.

During the implementation phase, resistance from various managers working in relief projects was observed. For example, during the implementation, one supply chain officer did not want to share the information needed for the defined performance indicators on one project in order to advance his own preferred indicators that had already been measured. To overcome this resistance, not only operational-level employees (supply manager, warehouse manager, pharmacists in the projects) but also members of the management team (supply chain officers, supply chain director and supply director at MSF Belgium) were incorporated in the project team (ID8). More specifically, the supply chain director was appointed as the team leader for implementing strategic indicators at MSF Belgium, and a supply chain officer as the team leader for implementing tactical and operational indicators in relief projects in various countries. The head of relief projects, in cooperation with the supply chain officers, had the authority to make decisions regarding implementation. For example, the heads of relief projects in Afghanistan and South Sudan and two supply chain officers at the headquarters in Belgium decided to pilot-test the performance indicators. This was possible because of the range of people present in the projects that possessed considerable knowledge about local conditions where the projects were running. As a result, the head of relief projects and the supply chain officers in Afghanistan and South Sudan were able to facilitate access to the relief projects in different villages and cities in Afghanistan and South Sudan that exposed the system to different cultures and to different levels of understanding of performance measurement.

Over the course of the performance management project, it grew into a larger, organisationwide, supply chain improvement initiative (ID6 and ID10). After introducing the new performance indicators, we were able to identify heads of relief projects in other countries 
besides Afghanistan and South Sudan who were responsible for providing reports on supply chain performance results to the supply chain director and who were interested in measuring the supply chain performance of their relief projects. To structure the implementation of performance management in the various relief projects in the different countries, the performance management project working group decided to organise supply chain performance measurement sessions during a one-week supply seminar. This supply seminar was organised by MSF Belgium, with the objective of discussing general supply chain improvements with supply-related employees representing 29 projects in a range of countries. During this week, the performance management project working group organised three sessions on supply chain performance management. In these, the performance management working group presented the developed performance indicators, demonstrated their application using data from 12 projects in Afghanistan and South Sudan, and showed the reported results (including performance improvements). Having seen the results in these sessions, several supply managers from various countries asked for an implementation-focused visit by the performance management working group to their relief projects. The performance management working group also solicited further inputs on performance indicator adjustments from the supply managers who attended the supply seminar. As a result, new issues concerning supply chain performance measurement arose (e.g. how to apply the system when projects share stocks since, in that situation, one cannot measure stock levels per project).

The supply chain performance measurement sessions during the supply seminar not only showed the relevance of sharing experiences across the organisation and presenting supply chain performance measurement as part of improvement efforts, it also clarified the contribution of supply chain activities to improving performance in the relief projects. This motivated the staff to use the new performance measurement approach in their daily work. After the supply-week seminar, visits to three relief projects in Zimbabwe were conducted, where data were collected to calculate the performance indicators. The visit to the relief projects lasted two and a half weeks. During this visit, daily meetings were organised by this study's researcher and the supply manager responsible in Zimbabwe to review the performance measurement's implementation and to take actions based on the monitored performance. In each meeting, current performance was analysed, and actions were initiated based on the indicators. For example, after measuring fuel costs, the number of delivery stops and the high frequency of deliveries to the same area, it became apparent that freight was often not consolidated due to urgent delivery requirements imposed by the medical department. The head of supply indicated that these performance indicators supported him in discussions with medical and financial departments by providing information on the impact of medical and financial decisions on supply chain performance. Dealing with cultural change and ensuring that employees understand the purpose of measuring performance is therefore essential (ID7).

As a result of this fieldwork, MSF Belgium decided to set up training sessions and seminars in various projects to achieve a common understanding of performance measurement in order to overcome cultural challenges, to ensure progress in performance measurement and to promote proactive behaviour by employees on different hierarchical levels (as also suggested by Nudurupati et al. (2011) and Gutierrez et al. (2015)).

In Table $\mathrm{V}$, the first column summarises the practices involved in implementing performance measurement and the second column describes the use of each practice in our project together with the tools applied. In the next section, we provide a reflection on performance management implementation practices. For this, we conducted interviews with the supply chain director, project leader and supply director of MSF Belgium to evaluate the applicability of the performance management practices. The reflection examines if the performance management practices work as they were intended to work.
Performance management practices 
JHLSCM

10,2

142

4.2.2 Reflection on performance management implementation practices. The interviewees argued that involving an external expert (ID9) in the design and implementation team was crucial in the design and implementation phases of a performance measurement system. The interviewees recognised that implementing performance measurement is a complex business for which they needed to bring in external competence as such experience was not available internally.

In the implementation phase, both management and operational employees were part of the team (ID8). According to the interviewees, this made it easier to obtain data from the relief projects. Two of the interviewees indicated that this also avoided difficulties in coordinating the resources used across projects (many MSF projects run in parallel).

The interviewees indicated that ID6 is important in ensuring an ongoing reflection on the activities of MSF Belgium and so determine the gaps between actual and desired performance as well as actions to close any gaps. For this purpose, the members of the performance management working group organised meetings and assignments during the supply seminar (such as the Excel sheet developed during the supply seminar; see Appendix 5). The interviewees argued that such activities need to be regularly repeated as such assignments initiate reflection and motivate employees. The interviewees believed that implementing the performance indicators as a companywide project (ID10) was a very useful approach since this had identified differences between countries and made it possible to design unified indicators. However, it was also indicated that a possible disadvantage of such an approach might be that employees felt additional workload pressures across all countries. The workshop during the supply seminar was instrumental in building consensus among countries. The interviewees supported the view that such workshops should be organised more often for different regions and should involve more people from the relief projects.

As a final step, the main researcher conducted a pilot study in Zimbabwe and applied the performance indicators in three relief projects in order to compare the performance of these projects, to increase organisational learning about performance measurement and to give explicit attention to cultural change and to operator training (ID7). Interviewees argued that investing in understanding different cultures and the education levels of people involved in performance measurement simplifies the implementation process and avoids attempts to disrupt it. The interviewees argued that there are differences among country employees in their level of understanding of performance measurement, and that this affects the ease of implementation and the type of support needed in different countries. A good understanding of this is pivotal to the successful implementation of a performance measurement project.

During the interviews, the supply chain director, the project leader and the supply director of MSF Belgium evaluated the relative importance of the various implementation practices. In general, the interviewees argued that ID7 is the most important practice, ID9 was seen as the second most important, ID8 and ID10 as the next most important followed, finally, by ID6. The reason why ID7 was seen as the most important was because providing training to employees in projects in the various countries enhances and improves their skills and knowledge on performance management and reduces the risk of the employees not using the performance management tools.

\section{Main findings and discussion}

We conducted action research at MSF Belgium over a period of four years to explore whether supply chain performance management design and implementation practices commonly applied in business organisations are appropriate for humanitarian organisations (HOs). To this end, we conducted a variety of workshops, meetings and interviews, and we conducted pilot tests. This study provided the following findings.

The first finding is that the ten performance management practices we applied are not all equally important for the successful design and implementation of performance management 
- although all the practices seemed to be required for the successful design and implementation of supply chain measurement at MSF Belgium. During the interviews that we held in 2018 to reflect on the performance measurement design and implementation practices, the interviewees all agreed that all the practices were important and prerequisites for successful design and implementation of performance measurement at HOs. However, according to the interviewees, two practices, ID3 and ID7, stood out as particularly important. Setting objective criteria (ID3) was seen as a key prerequisite by all the interviewees. One interviewee argued that setting and discussing objective criteria 'makes clear what the indicators should be used for because different MSF supply chains have to be considered, and it supports MSF employees in learning how to design indicators independently.' This result is in line with earlier findings (e.g. Taticchi et al., 2010; Melnyk et al., 2014). Paying explicit attention to cultural change (ID7) was evaluated as the most important practice. Three interviewees indicated that cultural acceptance is crucial because they work in environments where many cultures, competences and visions come together and influence the results of performance management implementations. This result is in line with Franco-Santos et al. (2012).

The second finding is that tools and techniques developed for designing and implementing supply chain performance measurement systems in and for business organisations are also relevant in a humanitarian context. This is in line with findings from the literature on humanitarian supply chain management (Schulz and Heigh, 2009). During the course of the four-year project, we applied a variety of tools and techniques from businesses such as workshops, the Analytical Hierarchy Process (AHP) (Saaty, 1980) and the technical sheet (Neely et al., 1997). We used workshops to solicit feedback on ideas and to discuss the different perspectives on problems with relevant stakeholders as recommended by Bititci et al. (2000). For example, we demonstrated the usefulness of the 'demand forecast accuracy' performance indicator. We showed how to obtain relevant data and how to measure 'demand forecast accuracy' using data from actual relief projects in Afghanistan. In addition, we presented how to analyse the obtained results and how to take the actions necessary to ensure appropriate stock levels in the relief projects while reducing airfreight costs. We observed that such an approach leads to greater consensus and reduces resistance from some employees in relief projects and at headquarters, an observation similar to what Bititci et al. (2004) noted in the business sector.

We also found that not all the techniques, for example AHP, worked as we had anticipated. The interviewees argued that AHP is difficult to use due to the large number of metrics and measures included in the performance measurement system. The interviewees criticised the AHP survey (Appendix 4), which involves pairwise comparisons of performance indicators, as too time-consuming and complex. This criticism is in line with findings by Wakchaure and Jha (2012). Given this feedback, we instead used an approach involving a technical sheet developed by Neely et al. (1997) to generate the purpose, format, target, responsibility, data source, reporting frequency and use for each performance indicator. Using a technical sheet for each indicator simplified selecting a limited number of relevant indicators and provided a structure to support the design process of indicators as indicated by Sousa et al. (2010).

The third finding is the need to connect the design and implementation of a performance measurement procedure to an IT project. Wouters and Wilderom (2008) have previously highlighted that data availability and related IT systems are essential for the effective design and implementation of a performance measurement system. MSF Belgium had recognised at an early stage that relying on data captured in a chaotic environment with unusable and incomplete information is problematic when attempting to design and implement performance measurements because the actual performance levels may be depicted incorrectly. Therefore, four months before starting the performance management project, a parallel IT project had been started at MSF Belgium to develop a unified supply chain IT
Performance management practices 
JHLSCM

10,2

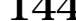

system for use around the globe. During the implementation of the performance management project at MSF Belgium, the supply chain director also got involved in the IT project and became the liaison between the two projects.

The fourth finding concerns the applicability of performance management practices used in business organisations to HOs. It is often stressed that business and humanitarian supply chains are very different (Abidi et al., 2014). However, the MSF performance management project, as well as the interviews with key stakeholders about the practices applied, showed that many of the design and implementation practices commonly found in business environments can also be applied in a humanitarian context, albeit with some adjustments. This finding is in line with Singh et al. (2018) who explained that the fundamental structure of the humanitarian supply chain is not so different from the business supply chain. For example, several metrics from the BSC and SCOR models can be used, but need adjustment to fit humanitarian supply chains (e.g. the demand/supply planning costs obtained from the SCOR model in a business environment was replaced by purchasing items under the control of MSF Belgium)[4], a finding supported by Abidi and Scholten (2015). Applying these practices may help in designing and implementing performance management that is aligned with an HO's strategies, philosophies and incentive schemes as is the case in the business sector. In a similar vein, Abidi et al. (2014) showed that the concept of fourth-party logistics service providers, which is well known in the commercial sector, may also be applicable to humanitarian organisations. The performance management practices presented provide a structured guide that can help ensure that the design and implementation of performance management at HOs remains manageable.

The fifth finding focuses on cultural change during performance management implementation in an organisation. During the reflection interviews, the interviewees put emphasis on paying attention to cultural change (ID7). The interviewees pointed out that considering cultural change and providing training to MSF employees in the field during performance measurement implementation is necessary and a new way of working for MSF. The performance management project led to a cultural change in the supply chain department at MSF Belgium. We observed that employees became less resistant to implementing performance measurement, and that the training sessions raised awareness of the importance of assessing supply chain performance. One interviewee indicated that 'cultural acceptance is crucial because we work in environments where many cultures, competences and visions come together. For example, in some countries employees gave little attention to the topic of performance measurement, resulting in inputting inaccurate supply chain data to the system.' In addition, employees from various departments at MSF Belgium realised that supply chain performance management can support them in monitoring efficiency, in comparing results with expectations, in encouraging discussions in meetings between executives and employees and between colleagues and donors, in providing accurate and timely information to decision-makers and in improving global performance.

Finally, the study at MSF showed that there may be a logic to the best order of applying the performance management design and implementation practices. Already during the exante project approval, we noticed that the understanding of performance management objectives and the design of the indicators have to be consistent among all the actors involved in the performance management working group at MSF in Belgium. Starting with ID4 and ID3 allowed consensus to be achieved among all the actors. In contrast, the literature argues that initially negotiating the goals is not a preferred approach (cf. De Leeuw and Van den Berg, 2011). We then focused in the design phase on practices ID1 and ID2 to structure indicators according to standard frameworks such as the BSC or a SCOR model.

In terms of a logic in the implementation steps, the supply chain director decided, before starting the project, to first appoint an external expert and a project team leader (ID9 and ID8) capable of guiding the organisational change. Next, ID6 and ID10 were recognised as crucial 
steps in the implementation phase of performance management at MSF in Belgium. Both implementing performance management as part of a company-wide project (ID10) and creating a performance management initiative (ID6) are considered advisable as these can facilitate the change process within an organisation (De Leeuw and Van den Berg, 2011). ID7 was regarded as the final but important step to avoid resistance among all the actors involved in implementing performance management. Such resistance might lead to staff lacking motivation to introduce improvements (De Leeuw and Van den Berg, 2011).

\section{Conclusions, limitations and future research}

Research on how to design and then implement supply chain performance management measures in humanitarian supply chains is limited (Abidi et al., 2014). Indicators commonly used by HOs do not cover all the relevant aspects of the humanitarian supply chain with, for example, reports for donors frequently focussing only on financial indicators (Beamon and Balcik, 2008). In essence, there is no common understanding of performance measurement and there are few tools and insights available in the literature on how HOs can design and implement supply chain performance management (Behl and Dutta, 2019).

\subsection{Theoretical implications}

The existing literature frequently claims that the performance of humanitarian and of business supply chain should be measured differently (e.g. D’Haene et al., 2015; Dubey et al., 2018). To the best of our knowledge, this paper is the first to provide an in-depth understanding of designing and implementing supply chain performance measurement procedures at an HO. In our research, we applied ten supply chain performance management practices identified in the business literature to a humanitarian supply chain. The first major theoretical contribution of our research is that, in terms of performance management design and implementation, humanitarian supply chains are no different from business supply chains. We have demonstrated that supply chain performance management at HOs can benefit from using performance management practices and tools already developed for the business sector. The first important implication that we derive from our findings is therefore that there is no good reason not to apply business performance management practices to humanitarian supply chains. Future research should explore whether other aspects seen in the business sector can also be successfully applied to the humanitarian sector, including the concepts of integrated supply chain management and process integration.

The second important implication is that tools and techniques, such as workshops and technical sheets, used in a business environment are also essential in designing and implementing performance measurement projects at HOs. For example, workshops were found to be a good way to establish a common understanding of performance management. Workshops also enhanced commitment to and engagement with implementing performance management in the relief projects as well as providing a means to obtain useful feedback. The technical sheet developed by Neely et al. (1997) proved to be a good instrument for providing a structure and visibility to each performance indicator and for supporting the implementation process of performance management in relief projects. Future research could usefully explore the applicability of process design and implementation tools and techniques common in business practice to humanitarian supply chains.

\subsection{Practical implications}

The first practical implication is that connecting performance management to an IT project is crucial in successfully implementing performance measurement in HOs. During our research, we observed that gathering data in a chaotic environment with unreliable, unusable and
Performance management practices 
JHLSCM

10,2

146

incomplete data information endangers the successful design and implementation of performance measurement at an HO. Wouters and Wilderom (2008) have highlighted that IT systems can lead to effective performance management. Future research is required to determine whether and how advanced technologies can be used to optimise performance and to increase visibility and predictability along the flow of physical goods as well as the complex flow of information and financial transactions in humanitarian supply chains and logistics networks (Wamba et al., 2017).

The second important implication is that performance management implementation requires a cultural change to reduce resistance by employees. Creating a performance improvement culture involves a systematic approach to managing the performance of organisations, teams and individuals and to reducing resistance. Our research showed, for example, that it is difficult for employees to create a shared consensus on how to effectively manage supply chain performance when they are not involved in the meetings and workshops from the start of a performance management project. Accordingly, future research could examine concepts for linking cultural change to desired supply chain performance concepts at HOs.

\subsection{Limitations and suggestions for future research}

As with any study, our study has its limitations. First, the key issue regarding validity in action research that uses one specific case is the questionable transferability of findings to other contexts (Thompson and Perry, 2004). Therefore, in future research, we would encourage multiple case studies to extend our findings to other organisations with different funding structures (MSF is known for its independence, with a large proportion of funds provided by individual donors) or different supply chain structures. Second, we have judged the applicability of business-based supply chain performance practices in humanitarian organisations using qualitative approaches. Providing stronger evidence for this applicability may require large-scale investigations such as a wider survey of performance measurement practices. Furthermore, it would be interesting to study a range of humanitarian organisations that are very different from each other.

In terms of the wider research agenda, there are two conclusions and recommendations for further research alongside those already identified. First, we identified that the availability of reliable, timely and accurate information is key to successfully managing humanitarian supply chain performance. Recently, HOs have started to invest in sophisticated information technology in the hope that this will improve information sharing, provide accurate forecasts or mitigate inventory fluctuations. Although technologies are available, it is not clear which information it is that managers require to manage processes in relief operations and to make the best possible decisions. As a result, it is difficult for volunteers, technology developers and logisticians to collect and analyse data such that this results in information that is accessible, reliable and relevant for decision-makers (Gralla et al., 2015). Indeed, our research also demonstrated that there is a lot of unusable and unstructured data in relief projects. Wamba et al. (2015) indicated that, once IT systems are in place, big data analytics will allow one to go beyond financial performance indicators and add value to customer, process and innovation perspectives that can promote and improve performance management and decision-making. Future research could therefore focus on examining the impact of big data and predictive analytics on humanitarian supply chains and organisational performance in a similar way to the research by Gunasekaran et al. (2017) has addressed the business environment.

\section{Notes}

1. Upside supply chain flexibility is included in the SCOR model and is a discrete measurement defined as the time it takes a supply chain to respond to an unplanned 20 per cent increase in demand without service or cost penalties. It shows the ability of a company or supply chain to respond quickly to an increase in order volume for a product. 
2. The AHP model was discussed by a group of researchers and practitioners in several meetings. A pre-test was conducted with the supply chain director and one of the authors. The final AHP survey (Appendix 4) was sent to the organisation's performance management group members $(n=6)$. These six experts were given two weeks to compare and to assess the relevance of each key performance indicator for each project level at MSF Belgium (headquarters (international), coordination, project site and project base levels) and for each key supply chain process determined (procurement, warehouse, distribution and supply chain planning).

3. Strategic level: headquarters (international), tactical level: coordination level, operational level: project site and project base levels. The four organisational supply chain levels involved in MSF's ordering and delivery process are described in detail in Saputra et al. (2015, p. 117).

4. Costs associated with forecasting, developing finished goods or end-item inventory plans, and coordinating the demand/supply process across the entire supply chain. This performance indicator includes the financial volume of items purchased under the control of MSF in place of the total amount purchased

\section{References}

Abidi, H. and Scholten, K. (2015), "Applicability of performance measurement systems to humanitarian supply chains”, in Klumpp, M., de Leeuw, S., Regattieri, A. and de Souza, R. (Ed.), Humanitarian Logistics and Sustainability, Springer, Cham, pp. 235-260.

Abidi, H., de Leeuw, S. and Klumpp, M. (2014), "Humanitarian supply chain performance management: a systematic literature review", Supply Chain Management: International Journal, Vol. 19 Nos 5/6, pp. 592-608.

Abidi, H., Dullaert, W., De Leeuw, S., Lysko, D. and Klumpp, M. (2019), "Strategic partner evaluation criteria for logistics service provider networks", International Journal of Logistics Management, Vol. 30 No. 2, pp. 438-466.

Ahmed, W., Najmi, A., Khan, F. and Aziz, H. (2019), "Developing and analyzing framework to manage resources in humanitarian logistics", Journal of Humanitarian Logistics and Supply Chain Management, Vol. 9 No. 2, pp. 270-291.

Anjomshoae, A., Hassan, A. and Wong, K. (2019), "An integrated AHP-based scheme for performance measurement in humanitarian supply chains", International Journal of Productivity and Performance Management, Vol. 68 No. 5, pp. 938-957.

Anjomshoae, A., Hassan, A., Kunz, N., Wong, K. and de Leeuw, S. (2017), "Toward a dynamic balanced scorecard model for humanitarian relief organizations' performance management", Journal of Humanitarian Logistics and Supply Chain Management, Vol. 7 No. 2, pp. 194-218.

Atkinson, M. (2012), "Developing and using a performance management framework: a case study", Measuring Business Excellence, Vol. 16 No. 3, pp. 47-56.

Baharmand, H., Comes, T. and Lauras, M. (2017), "Defining and measuring the network flexibility of humanitarian supply chains: insights from the 2015 Nepal earthquake", Annals of Operations Research, Vol. 283 No. 1, pp. 961-1000.

Balcik, B. and Beamon, B.M. (2008), "Facility location in humanitarian relief", International Journal of Logistics, Vol. 11 No. 2, pp. 101-121.

Balcik, B., Beamon, B.M., Krejci, C.C., Muramatsu, K.M. and Ramirez, M. (2010), "Coordination in humanitarian relief chains: practices, challenges and opportunities", International Journal of Production Economics, Vol. 126 No. 1, pp. 22-34.

Balcik, B., Bozkir, C.D.C. and Kundakcioglu, O.E. (2016), "A literature review on inventory management in humanitarian supply chains", Surveys in Operations Research and Management Science, Vol. 21 No. 2, pp. 101-116.

Bals, L. and Tate, W.L. (2018), "Sustainable supply chain design in social businesses: advancing the theory of supply chain", Journal of Business Logistics, Vol. 39 No. 1, pp. 57-79. 
JHLSCM 10,2

Battista, P. and Verhun, D. (2000), "Customer relationship management: the promise and the reality", CMA Management, Vol. 74 No. 4, pp. 34-37.

Beamon, B.M. (1999), "Measuring supply chain performance", International Journal of Operations \& Production Management, Vol. 19 No. 3, pp. 275-292.

Beamon, B.M. (2004), "Humanitarian relief chains: issues and challenges", Proceedings of the 34th International Conference on Computers and Industrial Engineering, University of Washington, Seattle, WA, Vol. 34, pp. 77-82.

Beamon, B.M. and Balcik, B. (2008), "Performance measurement in humanitarian relief chains", International Journal of Public Sector Management, Vol. 21 No. 1, pp. 4-25.

Beamon, B.M. and Kotleba, S.A. (2006), "Inventory management support systems for emergency humanitarian relief operations in South Sudan", The International Journal of Logistics Management, Vol. 17 No. 2, pp. 187-212.

Behl, A. and Dutta, P. (2019), "Humanitarian supply chain management: a thematic literature review and future directions of research", Annals of Operations Research, Vol. 283 No. 1, pp. 1001-1044.

Bititci, U.S., Mendibil, K., Nudurupati, S., Turner, T. and Garengo, P. (2004), "The interplay between performance measurement, organizational culture and management styles", Measuring Business Excellence, Vol. 8 No. 3, pp. 28-41.

Bititci, U.S., Turner, T. and Begemann, C. (2000), "Dynamics of performance measurement systems", International Journal of Operations and Production Management, Vol. 20 No. 6, pp. 692-704.

Bottani, E., Bertolini, M., Rizzi, A. and Romagnoli, G. (2017). Monitoring on-shelf availability, out-ofstock and product freshness through RFID in the fresh food supply chain, International Journal of RF Technologies, Vol. 8 No. 1-2, pp. 33-55.

Bourne, M., Kennerley, M. and Franco-Santos, M. (2005), "Managing through measures: a study of impact on performance”, Journal of Manufacturing Technology Management, Vol. 16 No. 4, pp. 373-395.

Bourne, M., Mills, J., Wilcox, M., Neely, A. and Platts, K. (2000), "Designing, implementing and updating performance measurement systems", International Journal of Operations and Production Management, Vol. 20 No. 7, pp. 754-771.

Braz, R.G.F., Scavarda, L.F. and Martins, R.A. (2011), "Reviewing and improving performance measurement systems: an action research", International Journal of Production Economics, Vol. 133 No. 2, pp. 751-760.

Cavalluzzo, K.S. and Ittner, C.D. (2004), "Implementing performance measurement innovations: evidence from government", Accounting, Organizations and Society, Vol. 29 No. 3, pp. 243-267.

Coghlan, D. and Brannick, T. (2010), Doing Action Research in Your Own Organization, 3rd ed., Sage, London.

Coughlan, P. and Coghlan, D. (2002), "Action research for operations management”, International Journal of Operations and Production Management, Vol. 22 No. 2, pp. 220-240.

Cozzolino, A. (2012), Humanitarian Logistics: Cross-sector Cooperation in Disaster Relief Management. Springer Science \& Business Media.

da Mota Pedrosa, A. (2012), "Customer integration during innovation development: an exploratory study in the logistics service industry", Creativity and Innovation Management, Vol. 21 No. 3, pp. 263-276.

De Leeuw, S. and Van den Berg, J.P. (2011), "Improving operational performance by influencing shopfloor behavior via performance management practices", Journal of Operations Management, Vol. 29 No. 3, pp. 224-235.

De Waal, A. and Kourtit, K. (2013), "Performance measurement and management in practice: advantages, disadvantages and reasons for use", International Journal of Productivity and Performance Management, Vol. 62 No. 5, pp. 446-473. 
De Waal, A.A. and Counet, H. (2009), "Lessons learned from performance management systems implementations", International Journal of Productivity and Performance Management, Vol. 58 No. 4, pp. 367-390.

D'Haene, C., Verlinde, S. and Macharis, C. (2015), "Measuring while moving (humanitarian supply chain performance measurement - status of research and current practice)", Journal of Humanitarian Logistics and Supply Chain Management, Vol. 5 No. 2, pp. 146-161.

Dubey, R., Luo, Z., Gunasekaran, A., Akter, S., Hazen, B.T. and Douglas, M.A. (2018), "Big data and predictive analytics in humanitarian supply chains: enabling visibility and coordination in the presence of swift trust", International Journal of Logistics Management, Vol. 29 No. 2, pp. 485-512.

Eltantawy, R., Paulraj, A., Giunipero, L., Naslund, D. and Thute, A.T. (2015), "Towards supply chain coordination and productivity in a three echelon supply chain: action research study", International Journal of Operations and Production Management, Vol. 35 No. 6, pp. 895-924.

Fagundes, L.D., Amorim, E.S. and da Silva Lima, R. (2017), "Action research in reverse logistics for end-of-life tire recycling", Systemic Practice and Action Research, Vol. 30 No. 5, pp. 553-568.

Ferreira, A. and Otley, D. (2009), "The design and use of performance management systems: an extended framework for analysis", Management Accounting Research, Vol. 20 No. 4, pp. 263-282.

Franco-Santos, M., Kennerley, M., Micheli, P., Martinez, V., Mason, S., Marr, B., Gray, D. and Neely, A. (2007), "Towards a definition of a business performance measurement system", International Journal of Operations and Production Management, Vol. 27 No. 8, pp. 784-801.

Franco-Santos, M., Lucianetti, L. and Bourne, M. (2012), "Contemporary performance measurement systems: a review of their consequences and a framework for research", Management Accounting Research, Vol. 23 No. 2, pp. 79-119.

Garengo, P., Biazzo, S. and Bititci, U. (2005), "Performance measurement systems in SMEs: a review and a research agenda", International Journal of Management Reviews, Vol. 7 No. 1, pp. 25-47.

Gatignon, A., Van Wassenhove, L.N. and Charles, A. (2010), "The Yogyakarta earthquake: humanitarian relief through IFRC's decentralized supply chain", International Journal of Production Economics, Vol. 126 No. 1, pp. 102-110.

Gralla, E., Goentzel, J. and Van de Walle, B. (2015), "Understanding the information needs of fieldbased decision-makers in humanitarian response to sudden onset disasters", in Palen, L. Buscher, M., Comes, T. and Hughes, A. (Eds), ISCRAM 2015 Conference Proceedings - 12th International Conference on Information Systems for Crisis Response and Management. Kristiansand, Norway, University of Agder (UiA).

Gunasekaran, A., Papadopoulos, T., Dubey, R., Wamba, S.F., Childe, S.J., Hazen, B. and Akter, S. (2017), "Assimilation of big data and predictive analytics for supply chain and organizational performance: a resource-based view perspective", Journal of Business Research, Vol. 70, pp. 308-317.

Gutierrez, D.M., Scavarda, L.F., Fiorencio, L. and Martins, R.A. (2015), "Evolution of the performance measurement system in the Logistics Department of a broadcasting company: an action research", International Journal of Production Economics, Vol. 160, pp. 1-12.

Haavisto, I. and Goentzel, J. (2015), "Measuring humanitarian supply chain performance in a multigoal context”, Journal of Humanitarian Logistics and Supply Chain Management, Vol. 5 No. 3, pp. 300-324.

Holguín-Veras, J., Pérez, N., Jaller, M., Van Wassenhove, L.N. and Aros-Vera, F. (2013), "On the appropriate objective function for post-disaster humanitarian logistics models", Journal of Operations Management, Vol. 31 No. 5, pp. 262-280.

Huang, G.Q., Zhang, X.Y. and Liang, L. (2005), "Towards integrated optimal configuration of platform products, manufacturing processes, and supply chains", Journal of Operations Management, Vol. 23 Nos 3-4, pp. 267-290.

Performance

management practices 
JHLSCM

10,2

Johnson, H., Johansson, M. and Andersson, M. (2014), "Barriers to improving energy efficiency in short sea shipping: an action research case study", Journal of Cleaner Production, Vol. 66, pp. 317-327.

Kaplan, R.S. and Norton, D.P. (2001), The Strategy-Focused Organization: How Balanced Scorecard Companies Thrive in the New Business Environment, Harvard Business Press, Harvard.

Kennerley, M. and Neely, A. (2002), "A framework of the factors affecting the evolution of performance measurement systems", International Journal of Operations and Production Management, Vol. 22 No. 11, pp. 1222-1245.

Kovács, G. and Spens, K.M. (2011), "Humanitarian logistics and supply chain management: the start of a new journal", Journal of Humanitarian Logistics and Supply Chain Management, Vol. 1 No. 1, pp. 5-14.

Richey, R.G., Kovács, G. and Spens, K. (2009), "Identifying challenges in humanitarian logistics", International Journal of Physical Distribution \& Logistics Management, Vol. 39 No. 6, pp. 506-528.

Kueng, P., Meier, A. and Wettstein, T. (2001), "Performance measurement systems must Be engineered”, Communications of the Association for Information Systems, Vol. 7 No. 3, pp. 2-26.

Lai, K.H., Ngai, E.W.T. and Cheng, T.C.E. (2002), "Measures for evaluating supply chain performance in transport logistics", Transportation Research Part E: Logistics and Transportation Review, Vol. 38 No. 6, pp. 439-456.

Lu, Q., Goh, M. and De Souza, R. (2016), "A SCOR framework to measure logistics performance of humanitarian organizations", Journal of Humanitarian Logistics and Supply Chain Management, Vol. 6 No. 2, pp. 222-239.

Marchand, M. and Raymond, L. (2008), "Researching performance measurement systems: an information systems perspective", International Journal of Operations and Production Management, Vol. 28 No. 7, pp. 663-686.

Meekings, A. (1995), "Unlocking the potential of performance measurement: a practical implementation guide", Public Money and Management, Vol. 15 No. 4, pp. 5-12.

Melnyk, S.A., Bititci, U.S., Platts, K., Tobias, J. and Andersen, B. (2014), "Is performance measurement and management fit for the future?", Management Accounting Research, Vol. 25 No. 2, pp. 173-186.

Micheli, P., Mura, M. and Agliati, M. (2011), "Exploring the roles of performance measurement systems in strategy implementation: the case of a highly diversified group of firms", International Journal of Operations and Production Management, Vol. 31 No. 10, pp. 1115-1139.

Najmi, A. and Makui, A. (2012), "A conceptual model for measuring supply chain's performance", Production Planning and Control, Vol. 23 No. 9, pp. 694-706.

National Performance Management Advisory Commission (2010), "A performance management framework for state and local government: from measurement and reporting to management and improving", available at: http://www.gfoa.org/national-performance-management-advisorycommission-releases-framework-state-and-local-governments (accessed 22 December 2017).

Neely, A., Gregory, M. and Platts, K. (2005), "Performance measurement system design: A literature review and research agenda", International journal of operations \& production management, Vol. 25 No. 12, pp. 1228-1263.

Neely, A. D., Adams, C. and Kennerley, M. (2002), "The performance prism: The scorecard for measuring and managing business success", London: Prentice Hall Financial Times.

Neely, A., Gregory, M. and Platts, K. (1995), ”Performance measurement system design: a literature review and research agenda", International Journal of Operations \& Production Management, Vol. 15 No. 4, pp. 80-116.

Neely, A., Richards, H., Mills, J., Platts, K. and Bourne, M. (1997), "Designing performance measures: a structured approach", International Journal of Operations and Production Management, Vol. 17 No. 11, pp. 1131-1152. 
Nudurupati, S.S., Bititci, U.S., Kumar, V. and Chan, F.T. (2011), "State of the art literature review on performance measurement", Computers and Industrial Engineering, Vol. 60 No. 2, pp. 279-290.

Oloruntoba, R. and Gray, R. (2006), "Humanitarian aid: an agile supply chain?", Supply Chain Management: An International Journal, Vol. 11 No. 2, pp. 115-120.

Oloruntoba, R. and Gray, R. (2009), "Customer service in emergency relief chains", International Journal of Physical Distribution \& Logistics Management, Vol. 39 No. 6, pp. 486-505.

Pateman, H., Hughes, K. and Cahoon, S. (2013), "Humanizing humanitarian supply chains: a synthesis of key challenges", The Asian Journal of Shipping and Logistics, Vol. 29 No. 1, pp. 81-102.

Pettit, S.J. and Beresford, A.K.C. (2009), "Port development: from gateways to logistics hubs", Maritime Policy \& Management, Vol. 36 No. 3, pp. 253-267.

Saaty, T.L. (1980), The Analytic Hierarchy Process, McGraw Hill. International, New York.

Saputra, T., Pots, O., de Smidt-Destombes, K.S. and de Leeuw, S. (2015), "The impact of Mean Time between Disasters on inventory pre-positioning strategy", Disaster Prevention and Management, Vol. 24 No. 1, pp. 115-131.

Scholten, K., Sharkey Scott, P. and Fynes, B. (2009), Supply Chain Management Concepts and Humanitarian Aid Agencies-An Exploratory Study.

Schön, A., Al-Saadi, S., Grubmueller, J. and Schumann-Bölsche, D. (2018), "Developing a camp performance indicator system and its application to Zaatari, Jordan", Journal of Humanitarian Logistics and Supply Chain Management, Vol. 8 No. 3, pp. 346-373.

Schreyer, M. (2008), Entwicklung und Implementierung von Performance Measurement Systemen, Springer, Wiesbaden, Vol. 56 No. 21, pp. 6809-6827.

Schulz, S. and Heigh, F.I. (2009), "Logistics performance management in action within a humanitarian organization”, Management Research News, Vol. 32, pp. 1038-1049.

Singh, R.K., Gupta, A. and Gunasekaran, A. (2018), "Analysing the interaction of factors for resilient humanitarian supply chain", Journal International Journal of Production Research, Vol. 56 No. 21, pp. 6809-6827.

Sousa, C.A.A., Nijs, W.F. and Hendriks, P.H.J. (2010), "Secrets of the beehive: performance management in university research organizations", Human Relations, Vol. 63 No. 9, pp. 1439-1460.

Stricker, N., Echsler Minguillon, F. and Lanza, G. (2017), "Selecting key performance indicators for production with a linear programming approach", International Journal of Production Research, Vol. 55 No. 19, pp. 1-13.

Supply Chain Council (2007), SCOR 8.0 Overview Booklet, Supply Chain Council Editions, 2000, available at: http://www.apics.org/apics-for-business/frameworks/scor (accessed 22 December 2017).

Tatham, P.H. and Hughes, K. (2011), "Humanitarian logistics metrics: where we are and how we might improve", in Tatham, M.C. and Tatham, P. (Ed.), Humanitarian Logistics: Meeting the Challenge of Preparing for and Responding to Disasters, Kogan Page, London, pp. 65-84.

Taticchi, P., Tonelli, F. and Cagnazzo, L. (2010), "Performance measurement and management: a literature review and a research agenda”, Measuring Business Excellence, Vol. 14 No. 1, pp. 4- 18.

Thompson, F. and Perry, C. (2004), "Generalising results of an action research project in one work place to other situations: principles and practice", European Journal of Marketing, Vol. 38 Nos 3/4, pp. 401-417.

Tung, A., Baird, K. and Schoch, H.P. (2011), "Factors influencing the effectiveness of performance measurement systems", International Journal of Operations and Production Management, Vol. 31 No. 12, pp. 1287-1310.

Ukko, J., Tenhunen, J. and Rantanen, H. (2007), "Performance measurement impacts on management and leadership: perspectives of management and employees", International Journal of Production Economics, Vol. 110 Nos 1-2, pp. 39-51. 
JHLSCM

10,2

152
Vega, D. (2018), "Case studies in humanitarian logistics research", Journal of Humanitarian Logistics and Supply Chain Management, Vol. 8 No. 2, pp. 134-152.

Wakchaure, S.S. and Jha, K.N. (2012), "Determination of bridge health index using analytical hierarchy process", Construction Management and Economics, Vol. 30 No. 2, pp. 133-149.

Wamba, S.F., Akter, S., Edwards, A., Chopin, G. and Gnanzou, D. (2015), "How big data can make big impact: findings from a systematic review and a longitudinal case study", International Journal of Production Economics, Vol. 165, pp. 234-246.

Wamba, S. F., Gunasekaran, A., Akter, S., Ren, S. J. F., Dubey, R. and Childe, S. J. (2017), "Big data analytics and firm performance: Effects of dynamic capabilities", Journal of Business Research, Vol. 70, pp. 356-365.

Wouters, M. and Wilderom, C. (2008), "Developing performance-measurement systems as enabling formalization: a longitudinal field study of a logistics department”, Accounting, Organizations and Society, Vol. 33 No. 4, pp. 488-516.

\section{Further reading}

Bhagwat, R. and Sharma, M.K. (2009), "An application of the integrated AHP-PGP model for performance measurement of supply chain management", Production Planning and Control The Management of Operations, Vol. 20 No. 8, pp. 678-690.

Brannick, T. and Coghlan, D. (2010), Doing Action Research in Your Own Organization, Sage, Thousand Oaks.

Da Mota Pedrosa, A., Naslund, D. and Jasmand, C. (2012), "Logistics case study based research: towards higher quality", International Journal of Physical Distribution and Logistics Management, Vol. 42 No. 3, pp. 275-295.

\section{Corresponding author}

Sander de Leeuw can be contacted at: sander.deleeuw@wur.nl 
Appendix 1

Performance

management practices

$\begin{array}{ll}\text { Beamon (1999) } & \text { (1) What is being measured? } \\ & \text { (2) How frequently is the measurement performed? } \\ \text { Neely et al. (1995, } & \text { (3) When and how are the measures re-evaluated? } \\ \text { 2002, 2005) } & \text { (2) Which performance measures are used? } \\ & \text { (3) What benefit do they provide } \\ & \text { (4) Are the measures related to the business units objectives? } \\ \text { (5) Are some measures used for benchmarking? Is there any measure that should } \\ \text { Kennerley and Neely } \\ \text { (2002) } \\ \text { (1) Does the measure definitely assess what it is supposed to assess? } \\ \text { (2) Can the data be promptly communicated and easily understood? } \\ \text { (3) Is there any possibility of ambiguity in data interpretation? } \\ \text { (4) Is it possible to take actions based on the data? } \\ \text { (5) Can the data be analysed quickly enough so that actions can be taken? }\end{array}$

\section{Appendix 2}

"Supply Chain PERFORMANCE Management MSF"

Key performance indicator

Title of Kpi

Purpose

Relates to

Target

Formula

Frequency

Who measures?

Source of data

Who acts on the data?

What do they do

Is it valuable or useless?

Comments 
JHLSCM

10,2

\section{Appendix 3}

\section{4}

What is your job title?

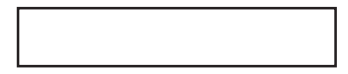

2) How long have you been working for your organization?

3) Gender

4) What type of supply is your organization managing?

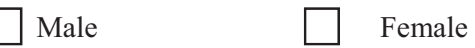

$\square$ Communications: radio, phones, internet, etc.

$\square$ Transports: trucks, cars, planes, cargo, horses, etc.

$\square$ Sources of energy: fuel, batteries, etc.

$\square \quad$ Accommodation or quartering

$\square$ Hygiene: water and sanitation

ㄱocurement: material, food, etc.

$\square$ Storage: warehousing and handling

Shipment: staff, food, special fittings, handling material, etc.

$\square \quad$ Education: seminars

$\square \quad$ Health: medicine

$\square \quad$ Other, please specify

5) What is your yearly budget which you manage and control for

a) Humanitarian relief

$$
\begin{aligned}
& \text { None } \\
& <1,000 \text { USD } \\
& <2,500 \text { USD } \\
& <5,000 \text { USD } \\
& >10,000 \text { USD } \\
& >50,000 \text { USD } \\
& <90,000 \text { USD } \\
& >100,000 \text { USD } \\
& >500,000 \text { USD } \\
& >2,000,000 \text { USD } \\
& \text { Don't know }
\end{aligned}
$$

b) Humanitarian logistics

$$
\begin{aligned}
& \text { None } \\
& <1,000 \text { USD } \\
& <2,500 \text { USD } \\
& <5,000 \text { USD } \\
& >10,000 \text { USD } \\
& >50,000 \text { USD } \\
& <90,000 \text { USD } \\
& >100,000 \text { USD } \\
& >500,000 \text { USD } \\
& \text { Don't know }
\end{aligned}
$$

6) What is the estimated number of beneficiaries that your organization attends to?
$\square \quad$ Less than 2000
Between 2000 and 10000
Between 10000 and 25000
Between 25000 and 75000
Between 75000 and 125000
More than 130000
Don't know 
7) Please indicate the degree of logistics outsourcing in your organization.

a) Please indicate the proportion of employees in your organization.

\begin{tabular}{|l|l|l|l|}
\hline White collar-worker & $\%$ & Blue collar-worker & $\%$ \\
\hline Field & & Field & \\
\hline Country & & Country & \\
\hline Region & & Region & \\
\hline Headquarter & & Headquarter & \\
\hline
\end{tabular}

b) For which country (ies)

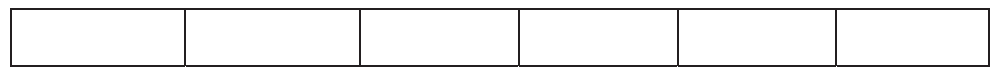

9) How do you define a humanitarian supply chain?

10) In case of disaster who are the supply chain actor in the process of supplying relief items?

11) What Objectives are central for your supply chain?

12) What decisions or actions are keys to these objectives?

13) How do you measure the success and goals of your supply chain?

14) Please asses the key performance indicator in your organization by allocation 100 points on each item. 0 point $=$ no usage/irrelevant 100 points $=$ high usage/extremely relevant

- Human resources indicator (e.g. total number of staff working hours)

- Financial indicator (e.g. supply chain costs)

- Process indicator (e.g. purchase order or number of stocks)

- Innovation indicator (e.g. implementation of ICT systems or supply chain concepts)

- Risk indicator (e.g. volatility index)

- Beneficiaries indicator (e.g. persons, location, countries served with aid)

15) How many information systems are used in the process of supplying aid to beneficiaries?

16) How many information systems are used in the process for capturing data?

17) Are the involved information systems interoperable?

a) If yes, what makes them interoperable?

b) If no, what can improve their interoperability?

18) Which of following key performance indicators have been captured in your organization?

\begin{tabular}{|c|c|c|}
\hline Objectives & Key performance indicators & $\mathrm{X}$ \\
\hline \multirow{4}{*}{$\begin{array}{l}\text { Responsiveness/ } \\
\text { Speed }\end{array}$} & Minimum response time & \\
\hline & Percentage of products that were delivered within promised lead time & \\
\hline & Delivery date reliability & \\
\hline & Donation-to-delivery Time & \\
\hline \multirow{2}{*}{$\begin{array}{l}\text { Achievement of } \\
\text { Objectives }\end{array}$} & Realised service level & \\
\hline & Degree of service & \\
\hline \multirow{2}{*}{$\begin{array}{l}\text { Beneficiaries and } \\
\text { Donors Satisfaction }\end{array}$} & Confirmation rate of customer's desired delivery date & \\
\hline & Complaint rate & \\
\hline \multirow[t]{2}{*}{ Reliability } & Delivery date reliability & \\
\hline & Delivery reliability & \\
\hline
\end{tabular}


JHLSCM 10,2

156

\begin{tabular}{|c|c|}
\hline & Complaint rate \\
\hline \multirow[t]{3}{*}{ Flexibility } & $\begin{array}{l}\text { Number of individual units of Tier } 1 \text { supplies that an organization can } \\
\text { provide in time period }\end{array}$ \\
\hline & $\begin{array}{l}\text { Mix of different types of supplies that the relief chain can provide in a } \\
\text { specified time period }\end{array}$ \\
\hline & $\begin{array}{l}\text { Number of individual units of Tier } 1 \text { supplies that an organization can } \\
\text { provide in time period }\end{array}$ \\
\hline \multirow{5}{*}{$\begin{array}{l}\text { Inventory } \\
\text { Performance }\end{array}$} & Accuracy of stock records \\
\hline & Stock efficacy \\
\hline & Mean costs per incoming goods item \\
\hline & Mean quality inspection costs per incoming goods item \\
\hline & Evaluated turnover rate \\
\hline \multirow{3}{*}{$\begin{array}{l}\text { Bottleneck } \\
\text { Management }\end{array}$} & Delivery quality reliability (Procurement) \\
\hline & Delivery quantity reliability (Procurement) \\
\hline & Delivery date reliability (Procurement) \\
\hline \multirow[t]{14}{*}{ Cooperation } & Framework agreement quota \\
\hline & Number of suppliers/logistic service providers \\
\hline & Number of externally sources articles \\
\hline & Information exchange quota \\
\hline & Order/setup costs \\
\hline & Inventory holding costs \\
\hline & Cost of Supplies \\
\hline & Number of relief workers employed per aid recipient \\
\hline & $\begin{array}{l}\text { Number of "value added" hours (the number of direct hours spent on } \\
\text { dispending aid per total number labour hours) }\end{array}$ \\
\hline & Dollars spent per aid recipient \\
\hline & Donor dollars received per time period \\
\hline & Evaluated turnover rate (distribution) \\
\hline & Mean costs for distribution activities per order-picking item \\
\hline & Mean costs of transport per goods consignment \\
\hline Standardization & Degree of standardization \\
\hline \multirow[t]{3}{*}{ Innovation } & Degree of investments in trainings \\
\hline & Degree of investments in information systems \\
\hline & Quota of supported processes by information systems \\
\hline \multirow[t]{4}{*}{ Costs Efficiency } & Total cost (of resources used) \\
\hline & Total Cost of distribution (including transportation and handling cost) \\
\hline & Inventory investment (the investment value of held inventory) \\
\hline & Inventory obsolescence (and spoilage) \\
\hline \multicolumn{2}{|r|}{ 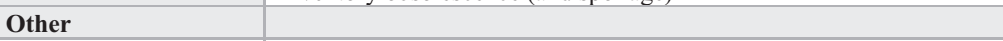 } \\
\hline Other & \\
\hline
\end{tabular}

19) Which measures have to be captured in your supply chain? (Qualitative and Quantitative)

20) Who should use the PMS?

21) How should be the performance measurement be designed?

22) Please tell us your evaluation for following questions. 


\begin{tabular}{|c|c|c|c|c|c|c|}
\hline \multicolumn{7}{|c|}{$\begin{array}{l}\text { Please tell us your assessment to the following aspects of the PMS in your humanitarian } \\
\text { organization. Our PMS ... }\end{array}$} \\
\hline & \multicolumn{2}{|c|}{ to a great extent } & \multirow[t]{2}{*}{$\rightarrow$} & \multicolumn{2}{|c|}{ not at all } & \multirow{2}{*}{$\begin{array}{l}\text { Don't } \\
\text { know }\end{array}$} \\
\hline & 1 & 2 & & 4 & 5 & \\
\hline \multicolumn{7}{|l|}{$\begin{array}{l}\text {...has a great value for our } \\
\text { management }\end{array}$} \\
\hline \multicolumn{7}{|l|}{$\begin{array}{l}\text {...has a very high acceptance } \\
\text { from our employees }\end{array}$} \\
\hline \multicolumn{7}{|l|}{$\begin{array}{l}\text {..has a very high acceptance } \\
\text { from our stakeholder (e.g. donor) }\end{array}$} \\
\hline \multicolumn{7}{|l|}{$\begin{array}{l}\text { pis of central importance for our } \\
\text { performance }\end{array}$} \\
\hline \multicolumn{7}{|c|}{ b) How familiar is your organization with the PMS in supply chains? } \\
\hline \multicolumn{7}{|l|}{ I use our PMS very often } \\
\hline \multicolumn{7}{|l|}{$\begin{array}{l}\text { I have a detailed substantive } \\
\text { understanding of our PMS }\end{array}$} \\
\hline \multicolumn{7}{|l|}{$\begin{array}{l}\text { I have a detailed understanding } \\
\text { of the costs which are linked to } \\
\text { the construction and maintenance } \\
\text { of our PMS }\end{array}$} \\
\hline \multicolumn{7}{|l|}{$\begin{array}{l}\text { c) To what extent do you agre } \\
\text { PMS? Our PMS ... }\end{array}$} \\
\hline & \multicolumn{2}{|c|}{ to a great extent } & $\rightarrow$ & \multicolumn{2}{|l|}{ not at all } & \multirow{2}{*}{$\begin{array}{l}\text { Don't } \\
\text { know }\end{array}$} \\
\hline & 1 & 2 & 3 & 4 & 5 & \\
\hline $\begin{array}{l}\text {...doesn't only consists of } \\
\text { financial ratios but also measures } \\
\text { performance and success along } \\
\text { several dimensions (e.g. process, } \\
\text { beneficiaries and innovation } \\
\text { ratios) }\end{array}$ & & & & & & \\
\hline $\begin{array}{l}\text {... ensures that all areas that are } \\
\text { relevant for the humanitarian aid } \\
\text { success are considered }\end{array}$ & $\mathrm{O}$ & $\mathrm{O}$ & $\mathrm{O}$ & $\mathrm{O}$ & $\mathrm{O}$ & $\mathrm{O}$ \\
\hline $\begin{array}{l}\ldots \text { offers a bride spectrum of } \\
\text { ratios (e.g. financial and non- } \\
\text { financial, internal and external, } \\
\text { early and late indicators) }\end{array}$ & $\mathrm{O}$ & $\mathrm{O}$ & $\mathrm{O}$ & $\mathrm{O}$ & $\mathrm{O}$ & $\mathrm{O}$ \\
\hline \multirow[t]{3}{*}{$\begin{array}{l}\text { d) To what extent do you a } \\
\text { operative humanitarian }\end{array}$} & $\begin{array}{l}\text { rree on the } \\
\text { relief in you }\end{array}$ & $\begin{array}{l}\text { ollowing st } \\
\text { PMS? Oı }\end{array}$ & $\begin{array}{l}\text { ements of th } \\
\text { PMS ... }\end{array}$ & combinatio & of strateg & and \\
\hline & \multicolumn{2}{|c|}{ to a great extent } & $\rightarrow$ & \multicolumn{2}{|l|}{ not at all } & \multirow{2}{*}{$\begin{array}{l}\text { Don't } \\
\text { know }\end{array}$} \\
\hline & 1 & 2 & 3 & 4 & 5 & \\
\hline
\end{tabular}

Performance management practices 
JHLSCM 10,2

\begin{tabular}{|l|l|l|l|l|l|}
\hline $\begin{array}{l}\text {.. creates causal connections } \\
\text { between value drivers on } \\
\text { operative level and output } \\
\text { quantity on strategic level }\end{array}$ & & & & & \\
\hline $\begin{array}{l}\text { aconnects all (operational) } \\
\text { activities with the achievement } \\
\text { of targets of the entire } \\
\text { organization }\end{array}$ & & & & & \\
\hline $\begin{array}{l}\ldots \text { shows how the humanitarian } \\
\text { operation relief activity of one } \\
\text { organization unit can influence } \\
\text { the entire organization }\end{array}$ & & & & & \\
\hline $\begin{array}{l}\ldots \text { ensures the compatibility of } \\
\text { personal performance targets and } \\
\text { appeals with the overall strategy } \\
\text { of the company }\end{array}$ & & & & & \\
\hline
\end{tabular}
of the company

e) To what extent do you agree on the following statements on focusing your PMS on relevant information? Our PMS ...

\begin{tabular}{|c|c|c|c|c|c|c|}
\hline & \multicolumn{2}{|c|}{ to a great extent } & \multirow[t]{2}{*}{$\rightarrow$} & \multicolumn{2}{|c|}{ not at all } & \multirow{2}{*}{$\begin{array}{l}\text { Don't } \\
\text { know }\end{array}$} \\
\hline & 1 & 2 & & 4 & 5 & \\
\hline $\begin{array}{l}\ldots \text { concentrates on relevant } \\
\text { information to success and } \\
\text { performance measurement on } \\
\text { basis of chosen ratios }\end{array}$ & & & & & & \\
\hline $\begin{array}{l}\ldots \text { creates strongly compacted } \\
\text { and focused performance and } \\
\text { success ratios on higher } \\
\text { hierarchical levels of the } \\
\text { organization. }\end{array}$ & & & & & & \\
\hline $\begin{array}{l}\text {... doesn't try to generate as } \\
\text { many measure values } \\
\text { as possible but to priorize the } \\
\text { most important ratios }\end{array}$ & & & & & & \\
\hline $\begin{array}{l}\ldots \text { has the right detail level for } \\
\text { the requirements of different user } \\
\text { groups }\end{array}$ & & & & & & \\
\hline
\end{tabular}

f) To what extent do you agree on the following statements of timely availability of information in your PMS? Our PMS ...

\begin{tabular}{|c|c|c|c|c|c|c|}
\hline & \multicolumn{2}{|c|}{$\begin{array}{l}\text { to a great } \\
\text { extent }\end{array}$} & \multirow[t]{2}{*}{$\rightarrow$} & \multicolumn{2}{|c|}{ not at all } & \multirow[t]{2}{*}{$\begin{array}{l}\text { Don't } \\
\text { know }\end{array}$} \\
\hline & 1 & 2 & & 4 & 5 & \\
\hline $\begin{array}{l}\text {.. ensures that ratios for the } \\
\text { operative daily activities are } \\
\text { measured more often than results } \\
\text { ratios }\end{array}$ & & & & & & \\
\hline $\begin{array}{l}\text {... ensures that information for } \\
\text { the performance and success } \\
\text { measurement are available } \\
\text { continuous and on time }\end{array}$ & & & & & & \\
\hline
\end{tabular}




\begin{tabular}{|c|c|c|c|c|c|}
\hline $\begin{array}{l}\text {... makes a quick reaction } \\
\text { between the performance } \\
\text { measurement and the der } \\
\text { correcting measures followed by } \\
\text { them possible }\end{array}$ & & & & & \\
\hline \multirow[t]{3}{*}{$\begin{array}{l}\text { o what extent do you } \\
\text { rganizations of your } P\end{array}$} & \multicolumn{2}{|c|}{$\begin{array}{l}\text { e followin } \\
\text { PMS ... }\end{array}$} & ements on co & inections across no & \\
\hline & \multicolumn{2}{|c|}{$\begin{array}{l}\text { to a great } \\
\text { extent }\end{array}$} & $\rightarrow$ & not at all & \multirow[t]{2}{*}{$\begin{array}{l}\text { Don't } \\
\text { know }\end{array}$} \\
\hline & 1 & 2 & 3 & 5 & \\
\hline $\begin{array}{l}\text {... gives us measurement } \\
\text { categories which connect our } \\
\text { intern activities with those of our } \\
\text { partners in the supply chain } \\
\text { (donors, beneficiaries, suppliers, } \\
\text { cooperation partners) }\end{array}$ & & & & & \\
\hline $\begin{array}{l}\text {... shows the connection of our } \\
\text { success with beneficiaries, donor } \\
\text { (e.g. efficiency) and } \\
\text { (sub-) suppliers (e.g. cost savings } \\
\text { in processes) }\end{array}$ & & & & & \\
\hline $\begin{array}{l}\text {...creates transparency regarding } \\
\text { performance and success } \\
\text { dependency between the } \\
\text { different participants in the } \\
\text { humanitarian supply chain }\end{array}$ & & & & & \\
\hline $\begin{array}{l}\text {.. integrates extern orientated } \\
\text { ratios (e.g. quality of operations } \\
\text { relief or performance of sub } \\
\text { suppliers) }\end{array}$ & & & & & \\
\hline $\begin{array}{l}\text {... ensures a compatibility of } \\
\text { ratios with those of our } \\
\text { humanitarian supply chain } \\
\text { partners }\end{array}$ & & & & & \\
\hline $\begin{array}{l}\text {... supports the coordination } \\
\text { with our humanitarian supply } \\
\text { chain partners }\end{array}$ & & & & & \\
\hline \multirow[t]{3}{*}{$\begin{array}{l}\text { h) To what extent do you a } \\
\text { PMS... }\end{array}$} & ree & llowin & ements on th & adaptability of yo & IS? Our \\
\hline & \multicolumn{2}{|c|}{$\begin{array}{l}\text { to a great } \\
\text { extent }\end{array}$} & $\rightarrow$ & not at all & \multirow[t]{2}{*}{$\begin{array}{l}\text { Don't } \\
\text { know }\end{array}$} \\
\hline & 1 & 2 & 3 & 5 & \\
\hline \multicolumn{6}{|l|}{$\begin{array}{l}\text {... can be adapted easily in case } \\
\text { of new knowledge or additional } \\
\text { requirements }\end{array}$} \\
\hline $\begin{array}{l}\ldots \text { is able to react flexible on } \\
\text { new requirements or situations }\end{array}$ & & & & & \\
\hline
\end{tabular}


JHLSCM

10,2

160
... can be adapted easily to our standard solution in contrast to our specific humanitarian aid requirements

i) To what extent do you agree on the following statements on the kind of use of your PMS? Our management uses our PMS ...

\begin{tabular}{|c|c|c|c|c|c|c|}
\hline & \multicolumn{2}{|c|}{$\begin{array}{l}\text { to a great } \\
\text { extent }\end{array}$} & \multirow[t]{2}{*}{$\rightarrow$} & \multicolumn{2}{|c|}{ not at all } & \multirow[t]{2}{*}{$\begin{array}{l}\text { Don't } \\
\text { know }\end{array}$} \\
\hline & 1 & 2 & & 4 & 5 & \\
\hline \multicolumn{7}{|l|}{$\begin{array}{l}\ldots \text { to track the progress in } \\
\text { gaining our targets }\end{array}$} \\
\hline \multicolumn{7}{|l|}{$\begin{array}{l}\ldots \text { to control central } \\
\text { humanitarian operations } \\
\text { indicators }\end{array}$} \\
\hline \multicolumn{7}{|l|}{$\ldots$ to monitor results, efficiency } \\
\hline \multicolumn{7}{|l|}{$\begin{array}{l}\ldots \text { to compare results with } \\
\text { expectations }\end{array}$} \\
\hline \multicolumn{7}{|l|}{$\begin{array}{l}\ldots \text { to bring the organization on a } \\
\text { common line }\end{array}$} \\
\hline \multicolumn{7}{|l|}{$\begin{array}{l}\ldots \text { to enable our organization } \\
\text { to concentrate on the critical } \\
\text { success factors }\end{array}$} \\
\hline \multicolumn{7}{|l|}{$\begin{array}{l}\ldots \text { to create an uniform } \\
\text { understanding in the organization } \\
\text { for the humanitarian aid targets }\end{array}$} \\
\hline \multicolumn{7}{|l|}{$\begin{array}{l}\ldots \text { to encourage discussions in } \\
\text { meetings between executives and } \\
\text { employees and between } \\
\text { colleagues and donors }\end{array}$} \\
\hline \multicolumn{7}{|l|}{$\begin{array}{l}\ldots \text { to make strategic decisions if } \\
\text { a quick reaction is necessary }\end{array}$} \\
\hline \multicolumn{7}{|l|}{$\begin{array}{l}\ldots \text { to make decisions when there } \\
\text { is an unclear problem that has } \\
\text { never appeared before }\end{array}$} \\
\hline \multicolumn{7}{|l|}{$\begin{array}{l}\ldots \text { to make decisions when there } \\
\text { was a similar problem in the } \\
\text { recent past }\end{array}$} \\
\hline \multicolumn{7}{|l|}{$\begin{array}{l}\text {... to anticipate the future } \\
\text { adjustment of the organization } \\
\text { instead of just reacting to given } \\
\text { problems }\end{array}$} \\
\hline \multicolumn{7}{|l|}{$\begin{array}{l}\ldots \text { to be able to make final } \\
\text { decisions in every case with high } \\
\text { strategic importance }\end{array}$} \\
\hline \multicolumn{7}{|c|}{$\begin{array}{l}\text { j) How do you evaluate performance of your organization in service quality compared to your } \\
\text { competitors? }\end{array}$} \\
\hline & to a gr & tent & $\rightarrow$ & not at all & & Don't \\
\hline & 1 & 2 & 3 & 4 & 5 & \\
\hline
\end{tabular}


The permanent fulfilling of the contracted delivery dates and amounts

The ability to concentrate on

customer wishes and needs

The part of deliveries with

missing/ wrong/ damaged

products

The observance of beneficiaries'

specifications

Your overall evaluation how the performance fulfills the

expectations of your internal and

external customers
Performance

management practices

\section{1}

23) What is your reflection on these questions? 
JHLSCM

10,2

162

\section{Appendix 4}

Working instructions:

Please compare which performance measurement indicators have to be esteemed important. Please use following rating scale:

$$
\begin{aligned}
& 1=\text { Equally important } \\
& 3=\text { Moderately important } \\
& 5=\text { Strongly important } \\
& 7=\text { Very strongly important } \\
& 9=\text { Extremely important }
\end{aligned}
$$

\begin{tabular}{|c|c|c|c|c|c|c|c|c|c|c|}
\hline & 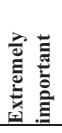 & 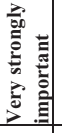 & 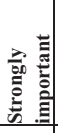 & 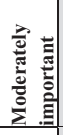 & 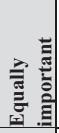 & 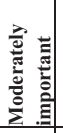 & 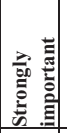 & 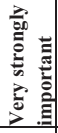 & 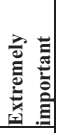 & \\
\hline Performance measurement indicator & 9 & 7 & 5 & 3 & 1 & 3 & 5 & 7 & 9 & $\begin{array}{c}\text { Performance measurement } \\
\text { indicator }\end{array}$ \\
\hline $\begin{array}{l}\text { Actual capacity to planned capacity } \\
\text { (human resources) }\end{array}$ & & & & & & & $\mathbf{X}$ & & & $\begin{array}{l}\text { Donations per } \\
\text { (project/country) }\end{array}$ \\
\hline
\end{tabular}

Please do not leave anything blank!

\section{For example 1):}

When you consider the supply chain area procurement which performance measurement indicator is ......important than the other performance measurement indicator at capital level?

\begin{tabular}{|c|c|c|c|c|c|c|c|c|c|c|}
\hline & 릴 & $\begin{array}{l}20 \\
\frac{20}{00} \\
0 \\
0 \\
0 \\
0 \\
0 \\
0\end{array}$ & $\begin{array}{l}\frac{2}{00} \\
\frac{0}{0} \\
\frac{\pi}{0}\end{array}$ & 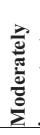 & \multirow{2}{*}{ 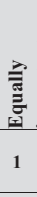 } & 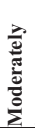 & 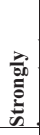 & 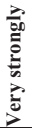 & 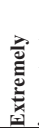 & \multirow[b]{2}{*}{ Performance measurement indicator } \\
\hline Performance measurement indicator & 9 & 7 & 5 & 3 & & 3 & 5 & 7 & 9 & \\
\hline Donations per (project/country) & & $\mathbf{x}$ & & & & & & & & Validation delay \\
\hline
\end{tabular}

Meaning: donations per project/ country is strongly important than actual capacity to planned capacity (human resources)

For example 2):

Meaning: Meaning Validation delay is strongly important than donations per project/ country. 


\section{Appendix 5}

For this interview/survey, the term Supply Chain Management (SCM) includes procurement and logistics, including warehousing and inventory management, and excludes fleet management. Please keep this in mind as you answer the questions.

The term "big project" refers to projects whose budgets exceed $\$ 1 \mathrm{M}$ over the life of the project.

Data should be from 2014 unless otherwise stated.

Financial numbers should be listed in USD.

Please provide an organigram for each country at a level which shows where SCM reports in.

OVERVIEW - SECTION 1. Country "numbers"

\begin{tabular}{|c|c|c|c|}
\hline & $\vec{E}$ & 己े & $\sum_{0}^{m}$ \\
\hline \multicolumn{4}{|l|}{$\begin{array}{l}2014 \text { est. number of direct } \\
\text { beneficiaries served }\end{array}$} \\
\hline \multicolumn{4}{|l|}{$\begin{array}{l}2014 \text { est. number of } \\
\text { indirect beneficiaries } \\
\text { served }\end{array}$} \\
\hline \multicolumn{4}{|l|}{$\begin{array}{l}\text { Total country budget in } \\
\text { USD (the most recently } \\
\text { amended budget) }\end{array}$} \\
\hline \multicolumn{4}{|l|}{$\begin{array}{l}\text { Percentage of country } \\
\text { budget allocated to } \\
\text { Emergency Response }\end{array}$} \\
\hline \multicolumn{4}{|l|}{$\begin{array}{l}\text { Name of department into } \\
\text { which SCM reports }\end{array}$} \\
\hline \multicolumn{4}{|l|}{$\begin{array}{l}\text { Percentage of country } \\
\text { budget allocated to SCM }\end{array}$} \\
\hline \multicolumn{4}{|l|}{$\begin{array}{l}\text { Number of Implementing } \\
\text { Partners (IPs) }\end{array}$} \\
\hline \multicolumn{4}{|l|}{ Number of SCM IPs } \\
\hline \multicolumn{4}{|l|}{ Number of Projects } \\
\hline \multicolumn{4}{|l|}{ Number of big Projects } \\
\hline \multicolumn{4}{|l|}{$\begin{array}{l}\text { Types of items } \\
\text { used/distributed: }\end{array}$} \\
\hline \multicolumn{4}{|l|}{ In kind commodities } \\
\hline \multicolumn{4}{|l|}{$\begin{array}{l}\text { Locally sourced } \\
\text { commodities }\end{array}$} \\
\hline \multicolumn{4}{|l|}{$\begin{array}{l}\text { Globally sourced } \\
\text { commodities }\end{array}$} \\
\hline \multicolumn{4}{|l|}{ MSF OCB STAFF } \\
\hline \multicolumn{4}{|l|}{$\begin{array}{l}\text { Total current number of } \\
\text { staff (Existing and } \\
\text { occupied positions) }\end{array}$} \\
\hline \multicolumn{4}{|l|}{$\begin{array}{l}\text { Total current number of } \\
\text { vacant posts (Existing } \\
\text { vacant plus New-vacant) }\end{array}$} \\
\hline $\begin{array}{l}\text { Turnover of staff (number } \\
\text { of posts vacated in 2013) }\end{array}$ & & & \\
\hline
\end{tabular}


JHLSCM 10,2

164

\begin{tabular}{|l|l|l|l|}
\hline $\begin{array}{l}\text { Current number of SCM } \\
\text { staff }\end{array}$ & & & \\
\hline $\begin{array}{l}\text { Current number of vacant } \\
\text { SCM posts }\end{array}$ & & & \\
\hline $\begin{array}{l}\text { Number of SCM posts } \\
\text { vacated in 2013 }\end{array}$ & & & \\
\hline MSF NATIONAL STAFF & & & \\
\hline $\begin{array}{l}\text { Total current number of } \\
\text { National Staff }\end{array}$ & & & \\
\hline $\begin{array}{l}\text { Total current number of } \\
\text { vacant National posts }\end{array}$ & & & \\
\hline $\begin{array}{l}\text { Number of National posts } \\
\text { vacated in 2013 }\end{array}$ & & & \\
\hline $\begin{array}{l}\text { Current number of National } \\
\text { SCM staff }\end{array}$ & & & \\
\hline $\begin{array}{l}\text { Current number of vacant } \\
\text { Nat'l SCM posts }\end{array}$ & & & \\
\hline $\begin{array}{l}\text { Number of National SCM } \\
\text { posts vacated in 2013 }\end{array}$ & & & \\
\hline
\end{tabular}

OVERVIEW - SECTION 2.

Country program and SCM detail. Please fill in for each country.

\begin{tabular}{|c|c|}
\hline \multirow{2}{*}{\multicolumn{2}{|c|}{$\begin{array}{l}\text { Country } \\
\text { Major donors }\end{array}$}} \\
\hline & \\
\hline \multicolumn{2}{|l|}{$\begin{array}{l}\text { Changes in donor requirements (over the last } 3 \\
\text { years) e.g increased use of local purchasing, } \\
\text { changes in reporting requirements or in procurement } \\
\text { guidelines. }\end{array}$} \\
\hline \multicolumn{2}{|l|}{$\begin{array}{l}\text { Recent program trends - } 2010 \text { to } 2014 \text { (growth, } \\
\text { funders, objectives, nature of activities) }\end{array}$} \\
\hline \multicolumn{2}{|l|}{$\begin{array}{l}\text { Expected future program trends }-2014 \text { to } 2020 \\
\text { (growth, funders, objectives, nature of activities) }\end{array}$} \\
\hline \multicolumn{2}{|l|}{ Supply Chain Management } \\
\hline \multicolumn{2}{|l|}{$\begin{array}{l}\text { SCM trends (stocks, in kind vs local markets, } \\
\text { objectives, nature of activities) }\end{array}$} \\
\hline \multicolumn{2}{|l|}{ SCM Strategic initiatives underway } \\
\hline \multicolumn{2}{|l|}{$\begin{array}{l}\text { Role of MSF in the supply chain (prime contractor?, } \\
\text { activities) }\end{array}$} \\
\hline \multicolumn{2}{|l|}{ Role of local government in the supply chain } \\
\hline \multicolumn{2}{|l|}{ Role of SCM Implementing Partners (IPs) } \\
\hline \multicolumn{2}{|l|}{$\begin{array}{l}\text { Trends in use of local markets (current split of in } \\
\text { kind vs locally purchased food, transport, non-food } \\
\text { commodities) }\end{array}$} \\
\hline \multicolumn{2}{|l|}{ SCM Information and IT } \\
\hline \multicolumn{2}{|l|}{$\begin{array}{l}\text { Type of SCM information system used by MSF \& } \\
\text { activities covered }\end{array}$} \\
\hline \multicolumn{2}{|l|}{ SCM IT Strategic initiatives that are underway } \\
\hline \multicolumn{2}{|l|}{$\begin{array}{l}\text { Types of reports currently used by MSF to monitor } \\
\text { SCM (check all that apply) }\end{array}$} \\
\hline \multicolumn{2}{|l|}{ Procurement plan } \\
\hline $\begin{array}{l}\text { Asset report (vehicles, telecom, computer } \\
\text { equipment, etc.) }\end{array}$ & \\
\hline
\end{tabular}




\begin{tabular}{|l|l|}
\hline Inventory report & \\
\hline Audit report & \\
\hline Other (list) & \\
\hline $\begin{array}{l}\text { Types of SCM information passed from IPs to MSF } \\
\text { electronically }\end{array}$ & \\
\hline $\begin{array}{l}\text { Types of SCM information passed from IPs to MSF } \\
\text { using paper forms }\end{array}$ & \\
\hline $\begin{array}{l}\text { Percentage of MSF/IP operating locations with } \\
\text { acceptable mobile phone coverage }\end{array}$ & \\
\hline $\begin{array}{l}\text { Percentage of MSF/IP operating locations with } \\
\text { acceptable internet coverage }\end{array}$ & \\
\hline
\end{tabular}

OVERVIEW - SECTION 3. Please provide background on 1 to 3 big projects from each country. We will focus on these projects when we conduct our interviews.

\section{3a. Project Information}

\section{COUNTRY}

\begin{tabular}{|c|c|c|c|}
\hline \multirow{2}{*}{\multicolumn{4}{|c|}{$\begin{array}{l}\text { Number of direct } \\
\text { beneficiaries served }\end{array}$}} \\
\hline & & & \\
\hline $\begin{array}{l}\text { Number of indirect } \\
\text { beneficiaries served }\end{array}$ & & & \\
\hline Donor & & & \\
\hline Project location(s) & & & \\
\hline Objectives/activities & & & \\
\hline $\begin{array}{l}\text { Measures of project/ } \\
\text { programme success }\end{array}$ & & & \\
\hline $\begin{array}{l}\text { Trends (growth, change in } \\
\text { activities, change in donor } \\
\text { requirements) }\end{array}$ & & & \\
\hline Project budget & & & \\
\hline $\begin{array}{l}\text { Percentage of project budget } \\
\text { allocated to Emergency } \\
\text { Response }\end{array}$ & & & \\
\hline $\begin{array}{l}\text { Strategic importance of } \\
\text { project to MSF }\end{array}$ & & & \\
\hline $\begin{array}{l}\text { Biggest programme } \\
\text { challenges }\end{array}$ & & & \\
\hline Year started & & & \\
\hline $\begin{array}{l}\text { Term of current contract e.g. } \\
2012-2014\end{array}$ & & & \\
\hline $\begin{array}{l}\text { Which organization is the } \\
\text { prime contractor? }\end{array}$ & & & \\
\hline Current number of MSF staff & & & \\
\hline $\begin{array}{l}\text { Current number of open MSF } \\
\text { posts }\end{array}$ & & & \\
\hline $\begin{array}{l}\text { Total number of } \\
\text { Implementing Partners (IPs) }\end{array}$ & & & \\
\hline Number of SCM IPs & & & \\
\hline $\begin{array}{l}\text { Role of local } \\
\text { government/ministries }\end{array}$ & & & \\
\hline $\begin{array}{l}\text { Types of items } \\
\text { used/distributed: }\end{array}$ & & & \\
\hline In kind commodities & & & \\
\hline
\end{tabular}


JHLSCM 10,2

\begin{tabular}{|c|c|c|c|}
\hline Locally sourced commodities & & & \\
\hline $\begin{array}{l}\text { Globally sourced } \\
\text { commodities }\end{array}$ & & & \\
\hline $\begin{array}{l}\text { Type of supply chain } \\
\text { (choose one): } \\
\text { Rapid Response }-<2 \mathrm{mos} \\
\text { Short Term }-2-6 \mathrm{mos} \\
\text { Long Term - }>6 \mathrm{mos}\end{array}$ & & & \\
\hline Biggest SCM Challenges & & & \\
\hline $\begin{array}{l}\text { - Specific to your } \\
\text { circumstances, geography, } \\
\text { seasonality }\end{array}$ & & & \\
\hline $\begin{array}{l}\text {-Others, e.g. lack of priorities } \\
\text { placed on SCM }\end{array}$ & & & \\
\hline $\begin{array}{l}\text { Who executes SCM } \\
\text { activities (donor, program, } \\
\text { MSF SCM, IP, private } \\
\text { sector, no one)? }\end{array}$ & & & \\
\hline Forecasting need & & & \\
\hline $\begin{array}{l}\text { Procurement to prepositioned } \\
\text { stock }\end{array}$ & & & \\
\hline $\begin{array}{l}\text { Procurement of non-pre- } \\
\text { positioned program items }\end{array}$ & & & \\
\hline Transport of items & & & \\
\hline Warehousing & & & \\
\hline Distribution to beneficiaries & & & \\
\hline $\begin{array}{l}\text { Disposition of excess or } \\
\text { expired materials }\end{array}$ & & & \\
\hline Reporting of stocks on hand & & & \\
\hline Reporting of quantities used & & & \\
\hline $\begin{array}{l}\text { Reporting of quantities } \\
\text { distributed }\end{array}$ & & & \\
\hline
\end{tabular}

\section{3b. Qualitative Questions (answer for each country):}

1. What are the key elements that currently define Value for Money for your projects?

2. What additional elements that define Value for Money should be added?

3. What is important to programs with regard to supply chains for these projects, and how is it changing?

4. What supply chain design features do you think are most important to meet goals of the project? Why are these the most important features? What is their impact on programs?

5. Is SCM involved in the planning stages of the project? If not, at what stage of the projects does SCM become involved?

6. How well are your IT systems currently capable of providing the information to track supply chain performance?

7. What would use of a common set of KPIs for SCM across MSF mean for your projects? How would use of a common set of SCM KPIs for the humanitarian sector help your projects?

8. What SC design features do you think are most important to meet goals of the project?

9. Please list 5 key challenges for your project, ranked from 1 (the most critical of the list) to 5 (the least critical of the list.)

10. Please list 5 key challenges for your supply chain, ranked from 1 (the most critical of the list) to 5 (the least critical of the list.)

11. What would having a common set of supply chain KPIs mean for your projects? 


\section{Appendix 6}

Performance management practices

Examples of Kpis

\begin{tabular}{|c|c|c|c|c|c|c|c|c|}
\hline & Purpose & Formula & $\begin{array}{l}\text { How do we } \\
\text { operationalize } \\
\text { this kpi? }\end{array}$ & $\begin{array}{l}\text { Can we } \\
\text { make a } \\
\text { target? }\end{array}$ & $\begin{array}{l}\text { What is an } \\
\text { appropriate } \\
\text { survey } \\
\text { period? }\end{array}$ & $\begin{array}{l}\text { Reg } \\
\text { Vs } \\
\text { Em } \\
\text { erg } \\
\text { enc } \\
\text { y } \\
\end{array}$ & $\begin{array}{l}\text { Efficie } \\
\text { ncy/Ef } \\
\text { fective } \\
\text { nes }\end{array}$ & Note \\
\hline \multicolumn{9}{|l|}{$\begin{array}{l}\text { Headquarter Level / } \\
\text { Procurement }\end{array}$} \\
\hline \multirow{2}{*}{$\begin{array}{l}\text { Delivery Lead Time } \\
\text { reliability }\end{array}$} & \multirow{2}{*}{$\begin{array}{l}\text { It expresses Actual } \\
\text { delivery Vs Requested } \\
\text { delivery }\end{array}$} & $\begin{array}{l}\text { Lead time international } \\
\text { procurement (1 month } \\
\text { late } / 1 \text { week late/ } 1 \\
\text { week in advance / } 1 \\
\text { month in advance No } \\
\text { of shipments not } \\
\text { delivered in time/total } \\
\text { no of delivered items* } \\
100 \\
\end{array}$ & & & & & & \\
\hline & & $\begin{array}{l}\text { Lead time national } \\
\text { procurement ( } 1 \text { month } \\
\text { late } / 1 \text { week late/ } 1 \\
\text { week in advance / } 1 \\
\text { month in advance No } \\
\text { of shipments not } \\
\text { delivered in time/total } \\
\text { no of delivered items* } \\
100\end{array}$ & & & & & & \\
\hline \multirow{3}{*}{ Demand accuracy } & \multirow{3}{*}{$\begin{array}{l}\text { Measures accurate } \\
\text { and timely demand } \\
\text { plan }\end{array}$} & $\begin{array}{l}\text { Forecast accuracy: } \\
\text { financial value of orders } \\
\text { matching with a } \\
\text { forecast }\end{array}$ & & & & & & \\
\hline & & $\begin{array}{l}\text { Demand planning } \\
\text { accuracy }\end{array}$ & & & & & & \\
\hline & & $\begin{array}{l}\text { RDD coherent with } \\
\text { Agreed Lead time: \% of } \\
\text { RDD < ALT - } 1 \text { week }\end{array}$ & & & & & & \\
\hline
\end{tabular}




\begin{tabular}{l} 
JHLSCM \\
10,2 \\
$\mathbf{1 6 8}$ \\
\hline
\end{tabular}

Appendix 7

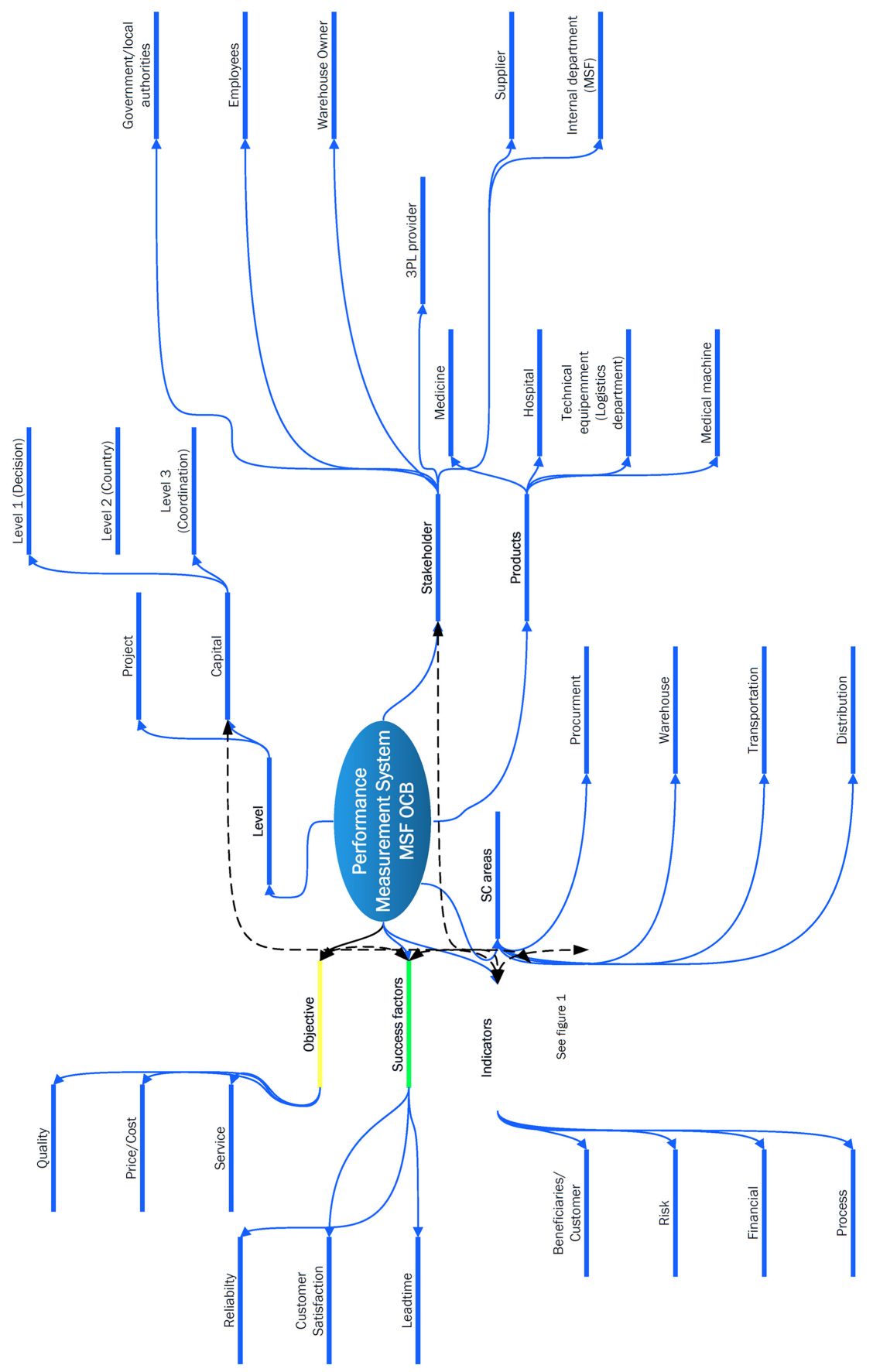

